\title{
The coherence of EU trade, competition, and industry policies in the high tech sector: the case of the telecommunications services sector
}

Citation for published version (APA):

Foray, D., Soete, L. L. G., \& Rutsaert, P. (1995). The coherence of EU trade, competition, and industry policies in the high tech sector: the case of the telecommunications services sector. MERIT, Maastricht Economic Research Institute on Innovation and Technology. MERIT Research Memoranda No. 011 https://doi.org/10.26481/umamer.1995011

Document status and date:

Published: 01/01/1995

DOI:

10.26481/umamer.1995011

Document Version:

Publisher's PDF, also known as Version of record

Please check the document version of this publication:

- A submitted manuscript is the version of the article upon submission and before peer-review. There can be important differences between the submitted version and the official published version of record.

People interested in the research are advised to contact the author for the final version of the publication, or visit the DOI to the publisher's website.

- The final author version and the galley proof are versions of the publication after peer review.

- The final published version features the final layout of the paper including the volume, issue and page numbers.

Link to publication

\footnotetext{
General rights rights.

- You may freely distribute the URL identifying the publication in the public portal. please follow below link for the End User Agreement:

www.umlib.nl/taverne-license

Take down policy

If you believe that this document breaches copyright please contact us at:

repository@maastrichtuniversity.nl

providing details and we will investigate your claim.
}

Copyright and moral rights for the publications made accessible in the public portal are retained by the authors and/or other copyright owners and it is a condition of accessing publications that users recognise and abide by the legal requirements associated with these

- Users may download and print one copy of any publication from the public portal for the purpose of private study or research.

- You may not further distribute the material or use it for any profit-making activity or commercial gain

If the publication is distributed under the terms of Article 25fa of the Dutch Copyright Act, indicated by the "Taverne" license above, 


\title{
THE COHERENCE OF EU TRADE, COMPETITION, AND INDUSTRY POLICIES IN THE HIGH TECH SECTOR: THE CASE OF THE TELECOMMUNICATIONS SERVICES SECTOR*
}

\author{
Dominique Foray, Pauline Rutsaert and Luc Soete**
}

Revised Version: February 1995

\begin{abstract}
We analyze the coherence existing among European Union competition, industry, and trade policies in the high tech sector in general terms focusing on its specific features (externalities, fast progress) and their effects on the emergence and treatment of policy consistency and conflicts. Second, this analysis is applied to the European telecommunications services sector. The examination of this sector and the relevant EU policies reveals a consensus on giving priority to competition. However structural factors prevent policy implementation to reflect much liberalization and harmonization and business responses to trade globalization challenge effective competition. The potential, important role of standardization is shown.
\end{abstract}

* Paper prepared for the International Conference on EC Policies on Competition, Industry and Trade: Complementarities and Conflicts, Louvain-la-Neuve, 27-28 October 1994.

** Respectively affiliated with IRIS-TS, Paris, Tinbergen Institute, Rotterdam, and MERIT, Maastricht. 


\section{INTRODUCTION}

Competition, trade, and industry policies all serve to achieve the objectives of the European Union as laid down in the Treaty of Rome, the Single European Act, and the Maastricht Treaty. However they feature different objectives and determine specific action spaces. It is thus useful to start the analysis by concisely stating the objectives of each of these three EU policies as applicable to the high tech sector on general and the telecommunications services sector on particular.

As for any other economic sector, EU competition policy aims at ensuring that competition in the union is not distorted. This is, to eliminate existing anti-competitive distortions and to prevent potential anti-competitive situations from emerging. For high tech sectors this means intense efforts especially in monitoring and disciplining state aids and public procurement as well as a careful examination of mergers and joint ventures taking into account the rapid pace of technological progress and potential consequences for competition. These competition policy objectives refer to the EU as a single market.

The objectives of the EU commercial policy are twofold. On the one hand the EU seeks the abolition of all tariff and non-tariff obstacles to the free movement of goods, capital, persons, and services between the EU member states. On the other hand it promotes, and participates in, the development of world trade and the lowering of trade barriers. Given the intensification of foreign competition, the shortening of product life cycles, and the increasing costs of developing new products and processes in high tech sectors, the EU aims at ensuring a minimum level of trade fairness and at supporting high tech firms through the implementation of strategic actions, the promotion of European norms, the constitution of entities of a critical, minimum size. In this case, trade policies reveals the $\mathrm{EU}$ as an agent in the world competition.

The industrial policy of the EU has been given an explicit status and content only recently, supplementing competition and integration policies and recommending an active intervention whenever member states policies are ineffective or harmful to other member states. The high tech sectors often represent areas in which the EU runs de facto an active EU industrial policy. The reason lies in the idiosyncratic features of that sector which commend cross-border strategies: importance of R\&D investments, international size of networks, need for compatibility of standards, convergence of technology know-how among various industries in the high tech sector. The high tech sector industrial policy follows three main lines of action. First, it tries to create the adequate conditions to exploit the sector's positive externalities (for example, by setting up an information infrastructure and network, by encouraging researcher mobility, by launching R\&D cooperation programs). Second, it seeks to maintain and develop technological diversity. This set of measures emphasizes the EU as a system of innovation.

Since the three policies under review are animated by different objectives and refer to three distinct dimensions of the EU, it is expected that the various ways through which they are implemented may at time reinforce each other and at other time conflict with each other. In our investigation of the coherence among these three policies in the high tech sector, we begin with a general analysis of the compatibilities and conflicts among the three policies paying especially attention to specific aspects of the high tech sector. (Section A). Then we explore in detail the case of the telecommunications services sector: first, we depict the sector in terms of structure, conduct, and performances (Section B); 
second, we describe the evolution of the EU trade, competition, and industry policies concerning the telecommunications services sector (Section C); finally, we analyze the coherence and conflicts existing among these policies (Section D).

\section{A. Analysis of Compatibilities and Conflicts among the Three Policies When Applied to the High Tech Sector}

To inquire into the issue of coherence among the competition, trade, and industry policies in the high tech sector may be done by answering the question: "What are the factors in this sector which induce the three actions spaces corresponding to the three policies not to necessarily and precisely overlap?". One way to handle this query is to distinguish three pairs of policies and to analyze each of them separately. In this section, such an analysis will be performed in general terms.

\section{A.1. Coherence Between Industry and Trade Policies}

Various externalities affect the high-tech sectors. The main sources of externalities are found at the R\&D level (knowledge and technological spillovers), and at the systems and networks operation level (where interoperability and interconnection matter).

The main clash between industry and trade policies is due to their treatment of different externalities. Indeed, any high tech generation process produces potentially two types of externalities. Negative externalities basically result from the possibility of appropriating the benefits of being first. Thus they appear in the circumstances defined by the "innovative race" and "winner-take-all" principles. Under certain assumptions, at the moment of the discovery, any agent who did not win the race will discard all resources (competence, instruments) allocated to this specific project. Such races are very common in the high tech sectors where the flow of innovations is usually continuous. Conditions of negative strategic externalities can conduct to both situations of over-investment (commons effect) and under-investment (public good effect) in research. Positive externalities derive from knowledge interactions driven by the properties of infinite expansibility (non rivalry) and cumulativeness. These suggest that the more is invented the easier it becomes to invent still more, provided of course that the conditions of wider distribution, and timely, inexpensive access to new findings are fulfilled. ${ }^{1}$ The difficulty is that the two types of externalities are not mutually exclusive (David and Foray, 1995). Indeed any process of knowledge generation -- either "scientific" or "technological" -- can generate potentially both types of externalities.

Whether the generation of knowledge is perceived as generating negative or positive externalities is thus a crucial point, influencing the design of the institutions, behaviors,

1 There has been a recent resugence of the view that in the realm of knowledge production positive externalities dominate. See P. Romer's emphasis upon not only the so-called "non-rival" character of ideas; see Scotchmer's work, in emphasizing the cumulative nature of inventive activity; and see David's (1993) attention to the impediments that intellectual property protection poses for further innovation, based on the related notion that a major use of new knowledge is as an input into further production of knowledge. 
norms of competition and cooperation, in the field of trade and technology policies. In general, industrial policy is viewed as oriented towards the management of systems which are perceived as "rich-in-positive externalities" whereas trade policy appears to be more focused on the perception of strategic negative externalities that are present in the system. ${ }^{2}$ Consequently, the policy responses to the perception of the system -as one that requires special incentives to reduce negative externalities (trade policy perception) or to fully realize the potential of positive externalities (industrial policy perception- are obviously difficult to harmonize. ${ }^{3}$ Indeed, these two types of externalities are referring to different analytical levels and can be characterized by different incentive structures.

On the one hand, numerous industry policy measures target a socially optimal exploitation of the positive externalities arising during the process of research and development of new products and new processes. These types of technology-cumindustry policy measures reflect a logic of openness in the sense that they attempt to enlarge the space and manners in which spillovers can be exploited in a welfareimproving way. On the other hand, several trade policy measures aims at lessening the welfare-reducing consequences of the negative externalities characterizing that same process. These measures reveal more a logic of closeness by which European high tech sector firms would be partially and/or temporarily protected from the technological leads and market moves from foreign firms. The goal of such a limited protection is to allow the European firms to adjust their marketing strategies and complete their R\&D projects in order to be better able to face foreign competition.

It is worth observing that the policy response chosen by each of these policies often leads to confirm the perception that caused the intervention and to strengthen the elements originally present in the system. Typically, the trade policy response to the perception of the system -- as one that requires special incentives to reduce negative externalities -involves the provision of strong protection for innovators, impeding the rapid disclosure of information. Similarly, under the industrial policy's perception of a system "rich-inpositive learning externalities", obstacles to information dissemination due to intellectual property rights and appropriation by secrecy are to be replaced with devices for coordinating the actions of innovative agents. For example, the intellectual property systems are to be valued because of their disclosure features and need not be used in ways that impede the pooling of knowledge.

The confrontation between the open logic and the closed logic shows in various situations. One of them is the issue of participation of foreign firms to European programs, such as those promoting R\&D cooperation or organizing the setting up of standards and norms. Advocates of active and strategic trade policy measures argue that non-EU firms be kept out of these programs. Among the justifications for such a stand, explicit reasons relate to the wish to keep EU public fundings benefiting EU firms and agents and to the possibility of developing a competitive advantage in that manner. But there are also hidden motivations such as the hope that outcomes of these European programs become a source of non-tariff barriers. In the meantime, industry policy would

2 Notice that competition policy makers can be viewed as "agnostic" with respect to the question of the nature of externalities which matter in high tech industries.

3 This section draws upon the Report "Accessing and expanding the science and technology knowledge base" (DSTI/STP/TIP(94)4) prepared by Paul A. David and D. Foray in the context of the OECD project on national innovation systems. 
recommend that these firms be part of these programs. Grounds for such a recommendation are, for example, that some valuable foreign knowledge might spill over to the European firms during the working sessions of these programs and that European standards should be chosen so as to minimize the risk of incompatibilities with foreign standards which might lead to costly standard wars. The present situation in the high tech sector seems to reflect various degrees of accommodation of this openness versus closeness conflict. In some areas, proponents of openness dominate; in some others, a closeness strategy is preferred. Another situation in which open and closed logics differ is that of technology transfer. Industry policy in the high tech sector -which often takes the form of technology policy- seeks to maximize the diffusion of knowledge and technology know-how given the relatively low transfer cost compared to the production costs. It thus encourages transfer know-how. At the same time, some of these transfers of technology towards foreign firms are actively regulated by trade policy interventions and systematic technology transfers from abroad appear to be sub-optimal and poorly managed at the EU level.

Beyond compatibilities and conflicts, it is important to observe the trend toward the convergence of trade and technology-cum-industry policies in the high tech sector. This convergence results from the vanishing of boundaries between the two types of policies. Two factors are identified as its cause: the increased global interdependence in economic and technological spheres and the growing involvement by governments in policies to promote innovation and technological advances. An interesting consequence of this phenomena is the use of some trade measures to palliate certain failures of technology policy and vice-versa the use of industry policies as a response to trade policy deficiencies. Typical examples are VERs in the former case and technical standards in the latter case.

\section{A.2. Coherence Between Competition and Trade Policies}

As concerns the EU competition and trade policies in the high tech sector, an important issue is the conflict between the primarily static approach of the antitrust law and the predominantly dynamic approach of the evolution of comparative and competitive advantages in a sector featuring quick technological change. It is often characterized by a trade-off between the intensity of short run competition and the maintenance of competitiveness in the medium and long run. The thorough study of this trade-off is typically a crucial part of the assessment of the desirability of state aids, mergers and take-overs in the high tech sector.

Such an evaluation work is very difficult because it is hard to predict the impact of these actions on potential competition and on the evolution of the trade pattern. The reason for this hardness lies in the characteristics of the high tech sector: short product life cycle, convergence of technologies among previously distinct industries, importance of standards and norms given the role of networks, prohibitive R\&D investments. The combination of these factors may drastically alter the market structure of the high tech sector in a short period of time. Consequently, the market structure of today may only tell very little about, and is no guarantee of, that of tomorrow. In face of this uncertainty created by successive and overlapping technological change exist two certainties: to fail the technical mastering of one product stage can be fatal to the survival of an industry and to keep up with all needed techniques requires abundant financial resources. This is so because of the tremendous cumulative learning taking place during the production and 
marketing of that product and because of the scale and complexity of innovative projects in the high tech sector.

Massive state and R\&D aids may be necessary to restore and/or maintain the competitiveness of an high tech industry while, at the same time, they may be unwanted because they deeply distort the market of that industry. Mergers and take-overs may cause a realization of scale economies necessary to remain competitive as well as provoke an increase in market power susceptible to ease anti-competitive strategies. Thus, trade policy-makers might seek to tolerate massive state aids in targeted industries and to sponsor the occurring of some mergers or take-overs whereas authorities in charge of competition policy might try to prevent them from taking place.

Trade and competition policies show another aspect of inconsistency when some trade measures create an environment propitious to the development of anti-competitive behaviors or when they strengthen industry concentration by lowering the impact of foreign competition. Indeed some procedures such as those by which VERs and antidumping actions can be initiated (e.g., major firms gather and make a case against unfair trade from a foreign importing country) are argued to be stimulative of inter-firm collaboration seeking shield from competition. In the same way foreign producers may collude in the bargaining of VERs with EU agents in a way that may reduce competition in the EU. Moreover the adequacy and the extent of protection of already highly concentrated industries might need to be put into question. The reason is that an increased protection of a domestic, concentrated industry has not been yet proved to be sufficient to restore incentive for innovation by domestic incumbents and/or entry by domestic entrants.

Still another kind of conflict between trade and competition policies concerns small and medium-firms. Trade policy measures striving to create entities of a critical size in which economies of scale can be achieved are likely to be detrimental to the viability of most smaller enterprises. As a result, they are likely to oppose that objective of the competition policy.

However it is obvious that many trade and competition measures are compatible. This occurs often when both sorts of measures target the achievement of higher level of competition. For example, the lowering of tariff and non-tariff barriers stimulate the free circulation of goods and so increase competition. This augmented competition is likely to be on turn an effective means to reduce the efficiency of anti-competitive practices, such as cartel behaviors. Another example is the opening up of public procurement markets which is expected to simultaneously serve trade policy objectives. Restrictive public procurement policies distort competition but also fragment markets according to national territories hindering trade. The opening up of public procurements will thus imply a reduction of anti-competitive practices as well as a liberalization of the trade in that market.

It is worth noticing that what seems at first to be a seed of conflict between trade and competition policies may turn out to be a source of compatibility. This will occur when some trade policy measure implemented to keep some domestic industry abreast with foreign competitors reveals itself in the long run as an effective mean to maintain some degree of competition at the world level. The initial fear of an immediate reduction of competition as a result of the trade measure might be more than compensated by the relief brought by the existence of some competition between the preserved domestic 
industry and a foreign industry that has become extremely concentrated.

\section{A.3. Coherence Between Competition and Industry Policies}

The principal clash between competition and industry policies arises around the issue of inter-firm agreements. The EU antitrust law is strict vis-a-vis inter-firm agreements: it seeks to prevent the formation of any such agreement which is likely to generate anticompetitive practices or a reduction of competition and to dismantle any of them which shows welfare-reducing effects. The EU industry policy considers inter-firm agreements in the high tech sector as an efficient way to internalize the positive technological externalities associated to knowledge production, to reduce wasteful duplication of R\&D investments, to improve the diffusion of new knowledge, and to optimize the selection of standards and norms. Indeed the high tech sector faces fast technological progress. Consequently firms should be given the possibility to adjust and participate to this technological change at low costs and in a manner that maximizes resource allocation. The management of these opposing views on the desirability of inter-firm agreements has led to a compromise: inter-firm R\&D cooperative agreements are exempted from notification requirement (1968 Notice on cooperation between enterprises relating only to $R \& D)$ and those $R \& D$ cooperative agreements which also include joint exploitation of the results also benefit from such an exemption provided that certain conditions are satisfied (1985 block exemption Regulation on R\&D agreements). Further effective flexibility vis-avis the European antitrust law has materialized as the Eureka program has developed promoting inter-firm agreements which strive to develop and commercialize new products and processes.

A grey area between competition and industry policies appears as concerns small and medium-firms. On the one hand, compatibility exists to some extent. Competition policy cares about the viability of small and medium-sized enterprises and industry policy encourages these same firms to participate in EC-sponsored R\&D programs. By these encouragements policy-makers in charge of industrial matters, besides their wish to see these firms get a fair share from the EC measures, may hope to achieve and/or maintain a greater technological diversity. Indeed it is generally agreed that small and mediumenterprises in the high-tech sector are often innovative, a source of dynamism and creativity complementary to the financial power and infrastructure strength of large firms. On the other hand, a conflict arises when EU R\&D programs in effect privilege a few large firms, when they are mainly determined by experts detached from, and caring for, large firms, or when they require too much administrative work for participation.

An additional possibility of grey zone between the two policies at stake concerns the intensity of competition prevailing on a market. On the one hand, the industry policy objective of maintaining a minimum technological diversity is likely to generate lower degrees of concentration in the market. This would mean that it comes close to one target of competition policy. On the other hand, the preservation of diversity among national system of innovation (one way to protect technological variety) might encourage firms to reply to this lack of harmonization by developing as multi-domestic firms. The emergence of multi-domestic firms can lead to a subtle but yet effective reduction of market competition through the development of coordinated oligopolistic behaviors across borders among the various subsidiaries. In addition, some EU R\&D programs effectively generate the selection and heavy subsidization of a few large firms. This industry strategy not only might distort the market selection process, but also might provoke an 
increase in market concentration and so ease the appearance of anti-competitive outcomes.

\section{A.4. Conclusions}

In this section, the coherence among the competition, trade, and industry policies in the high tech sector has been inquired by considering each pair of policies on turn. This exercise revealed the existence of several conflicts and compatibilities. The roots of these frictions often are found in the features of the high tech sector. These characteristics mainly, high level of R\&D expenditures, public good feature of a crucial intermediary output (knowledge), economies of scale and cumulative learning in innovation and production- are such that the tools used by each policy to attain its own objectives frequently oppose each other.

In the remaining of the paper, we explore that issue in the particular case of the telecommunications services sector. In Section B, the sector is described in terms of structure, conduct, and performances. In Section C, the EU competition, industry, and trade, policies concerning the telecommunications services are reviewed chronologically. In Section D, the coherence and conflicts among these three types of policies are analyzed.

\section{B. The Telecommunications Services Sector}

Telecommunications services are described in the Panorama of EU Industry 94 as "permit[ting] interactive interconnections between persons, between persons and computers and between machines, through many different media networks such as cable, microwaves and satellite networks. They also permit the diffusion of information from a single point to multiple points such as direct satellite broadcasting for television or data transmission."

The increasing importance of that sector is grasped by means of a few figures reflecting its performances (See Table 1 in Appendix). The revenues of these public TOs at the EU level amounted to ECU 90 billions in 1991 while their gross investments exceeded ECU 32 billions. The fastest growing sub-sectors are the mobile communications and the private networks (17 per cent increase between 1988 and 1990).

Another approach to the importance of the telecommunications sector is to assess the extent to which present economic activities depend on the use of information and telematic systems: more than 50 per cent of employment, or six out of ten jobs, are commonly accepted figures. ${ }^{4}$ It is expected that the telecommunications sector will the third largest, after food and drink and chemicals by the year 2000, and that as much as 30 per cent of its revenues would be associated with data and image transmission services. ${ }^{5}$ These forecasts have led to the coining of the term "information society": a society in which information and communication technologies (ITCs) would be an essential support

\footnotetext{
4 See European Parliament (1993) p.3, and Sun and Pelkmans (1994) p.6.

5 See European Parliament (1993) p.3,4.
} 
to human activities, could generate has much as 6 per cent of EU GDP by the end of the decade -the annual growth rates of the telecoms services and equipment markets being expected to amount to, respectively, 8 per cent and 4 per cent until the year $2000 .^{6}$

The remaining of this section is organized as follows: first, key elements characterizing the sector of telecommunications services are described first; second, recent technological change and its implications on market configuration are presented; third, the opening up of the market as a consequence of liberalization policy is depicted; fourth, the issue of telecommunications tariffs is examined; finally, information about investments and services quality and diversity are given.

\section{B.1. Key Features of the Sector}

The sector of telecommunications services is strictly regulated at each national level. An important result of these regulations is that in all but one Member States most telecommunications services are exclusively provided by one public telecom operator (TO) forced to comply to a set of obligations (such as provision of universal service, along with financial contributions to certain public R\&D expenditures and to the national budget). Another outcome of these regulations has been the development of a European telecommunications services market which is fragmented along national boundaries.

International telecommunications services are organized by means of a very stable regulatory mechanism which stipulates how revenues are shared among international carriers. This mechanism was devised by the International Telecommunications Union (based in Geneva). Modifications are brought to it when perceived as desirable by the ITU members and are adopted by its members during one of the world telecommunications conferences organized by the ITU. The revenues of each international carrier depend on the size of the international traffic it carries and on the tariffs set by the various carriers. Trade surplus or deficit in telecommunications services are largely determined by the differences existing among these diverse tariffs. ${ }^{7}$

The primary responsibilities of the TOs are the provision of the infrastructure and terminals necessary for telecommunications services as well as their maintenance. The infrastructure consists of the transmission networks (copper cables, optic fibers, satellites, etc.) and of the switching units (public or private, analogous or digital). The primary telecommunications service and terminal remains the telephone: eighty to ninety per cent of the public TOs' revenues is derived from basic telephony (See Table 2 in Appendix). ${ }^{8}$ However the variety and the sophistication of telecommunications services and terminals have been increasing over the last 15 years due to a sequence of technological innovations: fax, videotex, audiotex, mobile phone, radiopaging, visioconference, etc.

\footnotetext{
${ }^{6}$ See Sections 3.6 and 5.A of the White Paper "Growth, Competition, and Employment" (1994).

7 The EU usually faces a surplus with its main partner, the USA, because the international communication tariffs of its member states are high.

8 The telex service developed as an important complement to telephone services after the second world war but its use is steadily decreasing as new services provides similar possibilities with higher speed and quality. Consequently little more will be said about it.
} 
The vocal telephony service is run by a monopolist -namely the public TO- in all member states except in UK. There, a private TO, Mercury Communication, has been authorized to operate next to public TO, British Telecom, since 1984. The average level of penetration of basic telephone in the EU (42.2 lines per 100 habitants) is close to that observed in Japan (45.2) and not too far from that of the US (52.2). This EU level of penetration resulted from a 5 per cent average growth rate of extension and penetration of the EU network over the period 1982-1992 (in terms of main junction lines per subscriber). Two groups of users are usually distinguished: the residential customers and the business customers. The latter are more important than the former in terms of requirements and consumption: about 45 per cent of the basic telephony revenues come from business consumers although they only own 26 per cent of the total number of phone lines.

\section{B.2. Recent Technological Change and Implications for Market Configuration}

The market configuration has been substantially modified by a series of technological findings that occurred in the telecommunications technologies as well as in fields previously not related to it, such as computer and optic fiber technologies. The main developments are in transmission and switching techniques (from analogous mode to digital mode), in transmission support (fibre optics and satellite), and in advanced softwares and terminals.

The digitalization of information signifies that the information is transformed into bits (series of impulsion of the type 0 or 1). This implies that effective handling of the information is eased as well as made uniform across types of information (voice, data, or image). In turn, it simplifies the switching operation (reducing the costs of its monitoring and maintenance) and allows for new sorts of transmission supports to be used in networks.

One of these new supports is the optic fiber, made of glass and capable of conveying light. The technology of fiber optics evolved independently of the telecommunications technology. Its industrial applications were mainly developed by the glass industry (especially by Corning, an American firm) as one additional and promising application for glass. Due to digitalization, optic fibers can be used for transmitting information under the form of light impulsions. The major advantages of this type of transmission are its speed (about one million times faster than with traditional copper cable), its reliability and its low costs. ${ }^{9}$

Developments in the satellite technology lead to the manufacturing of more powerful antennas and more durable satellites, the exploitation of new frequency bands $(10 / 20$ $\mathrm{GHz}$ and 20/30 GHz; plus the experimentation of the $40 / 50 \mathrm{GHz}$ band), and the reduction in earth station size due to the reduction in antenna size. ${ }^{10}$ The benefits from

\footnotetext{
9 An example of the impact of the higher efficiency of this new support is the re-allocation of the transatlantic telecommunications traffic after the installation of an optic cable network across the Atlantic Ocean: away from the satellite network (which had previously expanded in respond to the low quality of the transatlantic analoguous cable network) towards the optic fiber network. See the 1990 Green Paper on a Common Approach in the Field of the Satellite Communication in the European Community.

10 The diameter of new antennas varies now between $0.5 \mathrm{~m}$ to $2.5 \mathrm{~m}$ instead of about $30 \mathrm{~m}$ previously. See the 1990 Green Paper on a Common Approach in the Field of the Satellite Communication in the European Community.
} 
these innovations will mostly be observable in the point-multipoint telecommunications applications because the point-point applications that the satellite networks used to handle are being more and more served by optic cable networks. ${ }^{11}$

The contributions of microelectronics and computer technology relate to the elaboration and design of advanced softwares and terminals. These softwares are needed to manage the digital commutation units, to monitor the private as well as public communication networks, and to elaborate new services.

The electronic information services are part of these new services; they are also called advanced services or value-added services (See Table 3 in Appendix). ${ }^{12}$ These services are mostly demanded and used by business customers, especially by those (such as lawyers, accountants, tax advisors, bank and insurance employees, etc.) whose profession requires frequent access to external information sources. The type of services demanded by the business community are financial, business, scientific, and technological information; those demanded by residential customers are entertainment services and information services (news, sports, financial).

To have access to the desired information business customers mainly use online ASCII databases and CD-Roms whereas the residential customers use cheap and user-friendly technologies such as audiotex and videotex (See Table 4 in appendix). ${ }^{13}$ The use of telecopy (also called facsimile or fax) and CD-Roms is well spread across both consumer groups. ${ }^{14}$ The present dominance of the facsimile as a text-based messaging technology is justified by the huge amount -46 billions- of pages sent and received by fax in $1993 .{ }^{15}$ Another service developing fast among business and government administration users is Electronic Data Interchange (EDI) and electronic mail. These last two value-added services allow their users to improve business efficiency by substituting electronic forms for their paper-based counterparts. ${ }^{16}$

Mobile telecommunications have increased a lot over the last ten years; it is the fastest

11 Satellites will remain important in handling point-point radio mobile communications in remote areas where terrestrial infrastucture is lacking. See the Financial Times Survey, Telecommunications in Business, 15 June 1994, p.VI.

12 VANS is the corresponding acronyme; it stands for value-added network services.

13 The audiotex service is accessible by means of a dial tone multi-frequency telephone and provides information services by means of recorded messages as well as other applications of general interest. The videotext service requires the availability of a terminal and of a regular telephone and provides various services; possibilities include information services, tourism and shows reservation services, entertainment sercives, up to home-banking and home-shopping services. It is mainly available in France (80 per cent of the existing videotex infrastructure in the EU) where it is called Minitel.

14 An interesting review of the evolution of the market for electronic information services was made part of the IMPACT Program. See COM(93), 156 final.

15 See the Financial Times Survey, Telecommunications in Business, 15 June 1994, p.VII.

16 For more information, see the Financial Times Survey, Telecommunications in Business, 15 June 1994, p.VII. 
growing segment of telecommunications services market. ${ }^{17}$ This increase was first due to the introduction of public cellular radiotelephony and later continued because of technological innovations (digitalization of mobile radiotelephony) which generated costs reductions and quality improvements.

The three most common mobile services are: private mobile radio, radiopaging, and analogous cellular radiotelephony. Digital cellular radiotelephony in Europe is based on a same pan-European norm GSM (Global System for Mobile communications) (See Table 5 in Appendix). ${ }^{18}$ The coherence that this norm generates at the European level for digital cellular telephony (as opposed to a lack of clear standard in the USA) proves to be a key factor in exporting the GSM in the Eastern Europe, in the Middle East, and the Asia/Pacific region (including, China, Hong-Kong, Singapore, Taiwan). ${ }^{19}$ However, the low number of commercial agreements among digital cellular network operators still limits the possibility of roaming (i.e., possibility of using the network of other digital cellular operators in the same country and/or in other countries). ${ }^{20} \mathrm{New}$ and/or more efficient digital mobile services are being developed; efforts sponsored by the European Telecommunications Standards Institute are made to design pan-European standards for them so as to maximize interoperability and interconnections.

The main technological consequence of these innovations is that each type of transmitted information (voice, data, or image) no longer requires the use of a specific network (respectively, telephone, telex, or packet switching). In other words, a same network (often referred to ISDN, Integrated Service Digital Network, or its future version, broadband ISDN) allows for the integrated distribution of all three information types. The potentials of such an ISDN network are described by experts as revolutionary. ${ }^{21}$ The multiple applications and services made possible by this network are expected to influence various aspects of life: work thanks to teleworking; education thanks to distance learning; research thanks to networks among universities and research centers; road circulation thanks to traffic management systems; air transportation thanks to air traffic control; health thanks healthcare networks; public procurement thanks to electronic tendering. ${ }^{22}$ Most of these services (for example, long distance learning, long distance

\footnotetext{
17 Mobile radiotelecommunications have existed in Europe since the 40s, but they have rapidly expanded since the mid-80s. The number of users of the three most common services have increased by more than 20 per cent in 1991, with an 40 per cent increase for analogous cellular radiotelephony. This last service represents more than 90 per cent of the whole EU mobile radio market. See the Green Paper on mobile telecommunications, COM (94) 145 final. At the world level, cellular phone subscribers increased to 32 millions between 1986 and 1993 with an annual growth rate of 45 to 59 per cent. See also the Financial Times Survey, Telecommunications in Business, 15 June 1994, p.III.

18 The GSM standard was elaborated through cooperative R\&D efforts sponsored by the EU. The number of its suscribers is still smaller than that of analogous cellular radiotelephony which benefits from an important installed basis.

19 See the Financial Times Survey, "Mobile Communications", 5 September 1994, p.III.

20 See the 1994 Green Paper on Mobile Telecommunications, p.128.

21 See, for example, the 1994 White Paper on Growth, Competitiveness and Employment, section 3.6, and the 1994 Bangemann Report.

22 See the Bangemann Report (1994).
} 
medical diagnosis) are already operational on a small scale, providing evidence of their possibilities and economic feasibility. ${ }^{23}$ The issue is thus no more whether or not such services will emerge, but when and how they will spread as well as their impact on society.

Another crucial effect of these innovations is observed on the structure of the supplier side of the market. Firms mastering neighboring technologies with growing importance for telecommunications as well as firms developing new telecommunications techniques try to enter the telecommunications service sector. They exert pressure on EU and national authorities to obtain a progressive liberalization of the new services markets. This last effect supplements the call for deregulation coming from the US and the UK. ${ }^{24}$ However strong these call and pressures, the degree of effective liberalization in the EU Member States is low on average, slowly increasing under the pressure of the EU legislation and under that of business customers. ${ }^{25}$

\section{B.3. The Liberalization Process}

The liberalization of the telecoms equipment market demanded by the 1988 EU Directive $(88 / 301 /$ EEC) was completed with a delay of three years due to a slow implementation in four countries (Belgium, Denmark, Germany, and Ireland). Indications of an increase in competition ensuing this Directive are seen in price reductions and in an augmentation of product diversity affecting, for example, mobile telephone handsets as well as switching units. ${ }^{26}$

The extent of the liberalization of all non-voice services (i.e., VANS) market to be achieved by 1990 according to the EU Directive (90/388/EEC) is still limited. New entrants complain about the lack of available leased lines as well as about the prices charged by

23 See the Financial Time Survey, "Telecommunications in Business", 15 June 1994, p.XII.

24 In the USA the commercial monopoly, AT\&T, was dismanteled in 1984 and since then the provision of long distance calls and value-added services is open and competitive. (For a quick recall and assessment of the effects of the AT\&T deregulation on its telecommunications services activities and on its telecommunications equipments productions, see the Communication of the Commission of 25th June 1992 concerning the European Telecommunications Equipments Industry: Situation, Stakes, and Propositions of Actions.) In the UK, a private TO Mercury received, in 1984, a licence to operate in parallel with British Telecom in all telecoms services. It is interesting to notice the difference in regulatory measures surrounding these two liberalizations in long distance call activities. In the UK customers are automatically connected with British Telecom unless they ask otherwise. In the USA customers must choose their long distance carriers on their own. This is said to explain why British Telecom still keeps 90 per cent of that market while AT\&T faces fierce competition from MCI, Sprint, and other long-distance carriers. See the Financial Times Survey, "International Communications", 17 October 1994, p.VI.

25 See next section for a description of the major modifications of the EU telecoms policies and legislations and see Appendix A for a table summarizing the EU regulatory environment in 1991.

26 See, for example, the Financial Time Survey, Telecommunications in Business, 15 June 1994, p.III. According to the head of Siemens' public communication networks group, prices for transmission and switching equipment have fallen, in real terms, by about 7 per cent during the last three years. See the Financial Times Survey, International Telecommunications, 17 October 1994, p.IV. 
public TOs to let them have an access to these lines. ${ }^{27}$

In some countries, the movement toward liberalization initiated by the EU legislations has expanded to other telecoms services that can still be legally provided on the basis of exclusive rights. This is especially visible in the area of mobile telephony. Several countries have allowed -or plan to allow- a duopoly for digital cellular telephony by selling a second licence to a private firm which would provide the service in competition with the public TO (which has the first licence). ${ }^{28}$ Where mobile phone operators compete prices decrease and the different equipment-tariff package offered to consumers reflect strategies used by the operators to differente one from another. ${ }^{29}$ The situation in the UK where four mobile telephony operators compete illustrates this well. In 1993, competition led the price of one minute of daytime call in the London region to fall from $33 p$ to $20 \mathrm{p}$ and then to $16 \mathrm{p}$. It also pushed some operators to offer free local calls on specific times and days, or as part of the monthly subscription rate. ${ }^{30}$

Another aspect of the supply-side structure change is the setting up of joint ventures and consortia among major TOs of different countries. ${ }^{31}$ These TOs justify such collaborative strategies as necessary to reach the critical size and the sufficient geographical needed to benefit from liberalization and essential in order not to loose in the likely, connected globalization in the telecoms services. However authorities in charge of competition fear that these alliances give too much market power to their members and hinder future competition in the market. In the last two years three global alliances proposing ambitious projects emerged. First an alliance, called Concert, between British Telecom (UK) and MCI (second largest long distance operator in the USA). Its objective is to develop one-stop voice and data services for multinaltionals. It has been approved by the US Department of Justice as well as by its UK equivalent. Second an alliance, called Atlas, among Deutsche Telekom, France Telecom, and Sprint (third largest long distance operator in the USA). Its objective is an efficient handling of telecommunications services for multinationals. It has not yet been approved by either the American or the EU antitrust authorities. Third an alliance, called Worldsource/Unisource, among the public TOs of Sweden, Switzerland, Netherlands, and Spain, and AT\&T. It is aimed at merging their international telecoms network in order to supply one-stop international telecoms

27 See the 1992 Review of the Telecommunications Sector by the European Commission, p.21-22. Sun and Pelkmans (1994) provide the following evidences: "The cost of a $200 \mathrm{~km}$ leased line between the UK and France is more than eight times more expensive than a leased line of the same distance within the UK only (Financial Times, 24 February 1994)."; "European wide-area connections or WANs (especially leased lines) can account for as much as 80 per cent of the total cost of setting up a network to link remote sites. This compares to about 35 per cent in the US (CommunicationsWeek International, 7 February 1994)."; "At present, more than 80 per cent of the EU's high-speed leased lines are located in the UK.... For the rest of the Union to catch up with the UK, an "infrastructure gap" equivalent to 130,000 circuits will have to be filled. This represents a five-fold increase on present levels (Ungerer, H., 1993, "Reconciling Telecommunications Liberalization and Trans-European Networks", Keynote Address, CEPS Focus on European Telecommunications and Competitiveness, 9 November).

28 See Appendix B for a table with the mobile communications services market structure in the EU and for a table with th GSM digital cellular tariffs.

29 See the comparisons of GSM digital cellular tariffs among AELE countries on p.V of the Financial Times Survey, Telecommunications in Business, 15 June 1994.

\footnotetext{
30 See the Financial Time Survey, Telecommunications in Business, 15 June 1994, p.III.

31 See the Financial Times Survey, "International Telecommunications", 17 October 1994, p.XI.
} 
services. In addition there are several consortia of less importance, such as the alliance among Air Touch (US), British Telecom (UK), and two Spanish banks (Airtel-ASR) for exploiting the second GSM licence in Spain, or the alliance between British Telecom (UK) and Ving (D) to build a network to offer data services to large corporate clients.

Besides mergers and alliances, the conduct of a telecommunications services supplier includes tariffs setting, investments in infrastructure, investments in research, delivery of telecom services and the obligation to fulfil certain regulatory requirements (such as supply of universal service at affordable rates, minimal financial contribution to the government budget).

\section{B.4. Issues of Pricing}

The tariffs proposed to users by any European TO are regulated by government and national authorities. The tariff of a service is usually composed of three elements: a connection charge (i.e., a fee for installing the connection between the user and the network), a subscription charge to be paid per period (every month or every two months) for keeping the right to use the connection and for having the services available, and a charge per call which differs according to the duration of the call, the time of the call (day or night, working days, weekends or holidays, etc.) and the location of the person which is called (within the local area, within the country, or abroad). For international calls, the tariffs and procedures according to which the revenues are shared among TOs are derived from rules and recommendations issued by an international organization, the International Telecommunications Union (ITU), and from bilateral agreements between firms or network owners. The core of the international charge is a sharing tax which serves as a basis for the revenues of the TOs. This tax is shared among the TOs of the countries through which the call transits (i.e., the countries of origin, of destination and of transit, if any).

The principal characteristics of the EU tariffs structure for basic telephony are: ${ }^{32}$

- The prices of local and national calls are low (i.e., below cost) and those of international calls are high (i.e., well above cost) ${ }^{33}$. The revenues from these high prices are partly used to subsidize the local and national call activity. The use of cross-subsidies has traditionally been justified as a means to increase the number of subscribers to a given network so as to comply with the "universal service" requirement and to exploit positive network externalities. That prices are not oriented to the costs is made possible by the monopoly structure for basic telephony.

- A strong frontier effect exists as concerns intra-EU calls. This effect shows in various ways. First, an 3-minute international call can be as much as 2.5 to 3 times more expensive than a national call of comparable distance in peak time periods (and up to 5 or 6 times in off peak periods). Second, the price of a call often varies a lot according to the

32 In order to understand the pricing behavior of the public TOs, it would be ideal to obtain information on their costs structures. Unfortunately this type of information is considered to be confidential and is not accessible.

33 Historically international calls were more expensive to supply and so required to be charged a high rate. The introduction of new technologies in the $60 \mathrm{~s}$ and 70 s reduced the production costs of these calls. However, the prices of these calls were maintained at their initial levels and the additional revenues from not adjusting the price to the costs were invested elsewhere in the network. 
country from which it originates; in particular, the price of a call in one direction can differ from that in the opposite direction by a factor of up to 2 .

- Divergence of practices among EU countries: some charge the same rate for all calls going to any country within the EU (i.e., independently of the distance, but still depending on the time of the call) whereas some others do not.

- Few discounts (i.e., small percentage of reduction as well as low number of hours during which some reduction applies) are offered in night time and weekend tariffs for intra-EU telephony compared to national telephony. ${ }^{34}$

The increase in competition in the long distance call activities in the US and the UK has led to a series of price-cutting moves that have benefited the customers of these countries. $^{35}$ This has also had an impact on the prices offered by European public TOs. Indeed as they did not revise international tariffs downwards while the costs were decreasing, new technological devices emerged to bypass the TO monopoly charges. ${ }^{36}$ And large business customers -using international calls intensively and bringing the most revenues to these TOs- started to use these devices and/or switch to the extent possible to rival TOs proposing lower prices. Consequently part of the traffic flows now reflects which TOs offer the most favourable rates although these flows are not justified on the basis of actual costs. Another outcome of these traffic diversions (which do not contravene any competition rule) is the loss of revenues for high tariff TOs. ${ }^{37}$

The numerous inefficient or perverse effects of the distorted tariff structure for telephony generated in 1988 a consensus among EU and national authorities in charge of telecommunications: to progressively orient the tariff structure toward costs. This led to efforts toward re-balancing charges across services according to their costs. Between 1980 and 1991, the tariffs decreased by about 2 per cent in real terms probably reflecting a similar reduction of costs: connection charges, subscription charges, and prices of long distance calls decreased while the prices of local calls increased. ${ }^{38}$ The modification in prices varied according to the countries and the type of network at stake. ${ }^{39}$ Additional improvements included the progressive generalization of pricing calls according to duration and the introduction of flexibility in the definition of local areas. The latter is aimed at reducing anomalies in tariff structure that may occur with calls among neighbors located in different calling areas. The first reduction in international taxes took place in

34 See Appendix $\mathrm{C}$ for tables concerning tariffs.

35 See the Financial Times Survey, "Telecommunications in Business", 15 June 1994, p.II

36 New technologies make possible traffic diversions. First, some TOs extend their network (mainly via satellite links) and so are able to offer international call services with a minimum transit on other TOs' networks. They benefit from their investment by charging less than would otherwise be charged because their lower prices attract intensive phone users. Second, equipments providing an automatic "call-me-back" feature are developed. This device leads to an automatic re-dial of any incoming call that originates from a country in which telephone charges are higher than those prevailing in the incoming country.

\footnotetext{
37 See the 1992 Review of the Telecommunications Sector by the European Commission, p.21.

38 See Appendix C.

39 Reductions are usually larger on the digital network than in the electro-mechanic one.
} 
1992, others followed, and further ones are to be expected. ${ }^{40}$ Some of these future reductions will affect the price of transatlantic calls because of the important increase in transmission capacity resulting form the installation of optic cables across the Atlantic Ocean. However besides all these changes, the intra-EU frontier effect remains quite strong and scope for further intra-EU tariff reductions exists. ${ }^{41}$

The issue of pricing is especially delicate for new telecom services in the EU. First, to find the adequate price level for these services matters: they should not be too low so as to allow the reimbursment of substantial initial investments and they should not be too high so as to attract rapidly a large customer base. ${ }^{42}$ Second, a conflict of interest emerges between the incumbent TOs and the entrants suppliers. One reason explaining this conflict is that most new services require the access to the existing infrastruture owned almost exclusively by public TOs. The other reason is that these new services generate a substitution away from old services exclusively provided by the public TOs. The EU TOs have thus little incentives to provide entrants with fair and quick access to the infrastructure because they do not want to loose revenues from the old services and because they also provide these new services. ${ }^{43}$ Third, the issue of universal service has to be clearly addressed. Today the public TOs are obliged to provide this service which is known to be unprofitable in several segments of the market. If new operators are allowed to compete with the incumbent public TOs for profitable advanced and valueadded services, they will reduce the revenue basis of the TOs. In order to prevent any competition distortion and maintain the quality of the universal service, new operators too should in some ways share part of this service burden. No precise agreement has been reached yet about how to regulate such an obligation. ${ }^{44}$ The combination of the

40 Indeed according to some observers the level of present ... taxes does not reflect real costs and derives from cartel behavior from the part of major public and private TOs. The percentage of tax -65 per cent to 85 per cent on a per unit price of expensive intra-EU calls in 1991- does not invalidate this fact. See European Commission, SEC(92) 1050 final p.16.

41 This is illustrated by the statistics found in the 1992 Review by the European Commission (p.19): between 1984 and 1992 US interstate telephone tariffs fell on average by 9.7 per cent per year in real terms, while between 1980 and 1990 intra-EU tariffs fell on average by 3.5 per cent per year in real terms.

42 In mobile telephony, prices have on average decreased (60 per cent of GSM operators reduced their price between June 1993 and June 1994) but in some place they have increased. See the Financial Times Survey, Telecommunications in Business, 15 June 1994, p.V.

43 Evidences have been found that public TOs often hinder the opening up of the market and distort competition in various ways. The case of cross-subsidies by the Deutsche Telekom illustrates this well: transfer of DM 1.9 billion from protected services to competitively supplied services. According to the EU Competition Commissioner, firms which have evidences concerning the abuse of dominant position by their TOs refuse to lodge formal complaints for fear of reprisals. See the Financial Time Survey, Telecommunications in Business, 15 June 1994, p.IV.

44 See Sun and Pelkmans (1994). Notice that the experience of liberalized telecoms markets, such as in Sweden or the UK, suggests that the cost of universal services is not as high as public TOs would like politicians and regulators to believe. In these liberalized markets the provision of universal services has not worsened with the increase of competition in long distance telecommunications and firms active in these services have not shown signs of lower profitability. These facts would mean that public TOs need the maintainance of their monopoly status for other reasons than universal services, such as to fulfil their financial contribution requirement, to hide an employment policy or inefficient management. See the Financial Times Survey, "Telecommunications in Business", 15 June 1994, p.IV; the Financial Times Survey, "International Telecommunications", 17 October 1994, p.II, IV, XII. 
three factors just mentioned has had an important repercussion on the pace of introduction of new services -too slow- in the EU as well as on their prices -too high. It is observed that in the UK where effective liberalization is at an advanced stage, the introduction of new services has been fast and that competition has led to price reductions. $^{45}$

Substantial investments in infrastructure have been observed in all EU countries. They have mainly been carried by the public TOs. Part of these investments is used to improve the network: modernization of switching centers so as to generalize direct international calling and thus make it cheaper on the one hand, and upgrading of existing transmission equipments so as to reduce transmission costs and to make the price of a call less dependent on distance on the other hand. The rest is aimed at expanding the network in areas which are not yet well served (low density population areas and areas difficult to reach) as well as installing the new special lines and switching units required to provide advanced services. Two categories of such lines are distinguished: those for the Integrated Services Digital Network (speed of voice telephone call is 64 kilobits per second and high-speed transmission reaches 2 megabits per second) and those of the broadband network (transmission speed allowing for high through-put such as video message: 140 megabits per second). Bits of an ISDN network are slowly built especially in large urban areas in which there is sufficient demand for the services carried by the ISDN. Elements of a broadband network are developed as part of experiments. ${ }^{46}$

Although the EU policy provides a useful framework and support for introducing new technology based networks, the 1992 Review of the Situation in the Telecommunications Services Sector of the European Commission indicates that the development of these networks is insufficient and suboptimal. First, the number of lines supplied for new services provision is low and its growth rate is weak. This leads to lengthy waiting lists (up to several years) for installing these lines and for connecting them to the basic infrastructure in many places. Second, a major issue of intra-EU interoperability and interconnection among the various existing bits of ISDN arises because all member states dit not choose the same standard. These two factors result in an unequal offering of new services across the EU. The EU framework has been used to prevent further lack of intraEU interoperability in other advanced applications. Success is achieved in mobile telephony where a pan-European standard, GSM, has been adopted; further similar efforts are made to reach a consensus concerning broadband transmission standards.

\section{B.5. Investments, and Services Quality and Diversity}

Public TOs invest mainly in two areas: infrastructure and R\&D. Total gross investments by EU public TOs have increased over the last decade (See Table 6 in Appendix).

This increase is especially visible in Portugal, Spain, Grece, and Germany (after reunification) and reflects the need for these countries to expand and/or upgrade their

45 See the Financial Times Survey, "International Telecommunications", 17 October 1994, p.VI.

46 The cost of the required investments in networks for the 1994-1995 period is ECU 20 billions for the installing the broadband network and ECU 15 billions for upgrading the ISDN network. See the table: "TransEuropean Telecommunications Networks: Propositions" in Section 3.6. of the 1994 White Paper on Growth, Competitiveness, and Employment. 
network. The main reason for the increase in investments is the digitalization of telecommunications and its implications. First it required substantial investments in the research and development of the digitalization techniques. Then it induced large investments in upgrading the infrastructure accordingly: construction of digital switching units and installation of optic fiber networks.

Investments in telecommunications R\&D by public TOs vary across the EU. In some countries, such as France, the TO is the largest contributor to private R\&D in the telecommunications sector whereas in others, such as Germany, the equipment manufacturers are the largest investors. On the average, the public TOs contribute between 20 and 25 per cent to R\&D expenditures in the telecommunications sector (a low percentage of which being is used to finance external R\&D). However the close examination of the national $R \& D$ systems reveals that in all countries there exists a close cooperation between public TOs and manufacturers. ${ }^{47}$

The provision of telecommunications services can be described by means of its quality and diversity. Studies on the European telecom sector highlight how the TOs'price setting policy and their infrastucture and R\&D investment strategies have led to a lower quality and a reduced diversity of their services compared to what is available in the USA. ${ }^{48}$ The lower quality is mainly reflected through longer waiting period before connection (whether for basic telephony or new services), smaller number of public phone boots, lower density of the network in terms of traditional and new transmission lines, and higher frequency of interferences or interruptions. The reduced diversity results from a slowlier pace of adoption of new services. This is mainly caused by the regulatory context giving exclusive rights to one $\mathrm{TO}$ and so protecting it from strong competitive pressures towards infrastructure modernisation and product innovation. In particular, the tariff structure that has arised in that context is identified as the source of a vicious circle: high prices discourage demand; this in turn provides low incentives to invest in infrastructure and new services and requires the maintainance of high prices in order to recover costs.

The quality and the diversity of telecom services in the EU has improved -especially as regards basic telephony- since the 1987 Telecommunications Green Paper and the expression of a European will to make telecommunications a priority. As it has been shown in precedent paragraphs, the result of several policy measures adopted by the EU and the member states is an increase of competition in the terminal equipment and value added service markets after their liberalization. In these markets, competition and marketing innovations by incumbent and new participants have led to cost reductions which in turn benefited customers through lower prices (especially those of customer premises equipments and mobile telephony). However, as various reports indicate it, many more efforts have to be done in order to reach a satisfactory situation in terms of pricing, supply of, and access to, high-speed lines and diversity and volume of new

47 For more detail, see Grupp and Schnoring (1992).

48 The U.K. in which liberalization started in 1984 with the authorization for a private carrier to supply telecommunications services is considered as the EU state offering the best price-quality-diversity combination. See the Financial Times Survey, "Telecommunications in Business", 15 June 1994, p.IV and X. 
advanced services. ${ }^{49}$

This brief survey of the telecommunications services sector first reveals that a stream of technological innovations have been taking place in this sector substantially modifying its role in the economy. It also points out to the difficulties generated by existing national regulations and public TOs' behaviors to adjust to, and efficiently exploit, this technological dynamics. In response to the technological change and the growing awareness of the role of telecommunications services in economic growth and competitiveness, the EU authorities acted toward creating an environment which would allow the EU to benefit from this evolution. In the next section, the EU policies concerning the telecommunications services sector are described.

\section{SECTION C: The Development of the EU Policies in the Telecommunications Services Sector: Trade, Industry, and Competition Policies}

European policy in the sector of the telecommunications services was almost non-existent until the 80s. Indeed until then this sector was excluded from the scope of the Common Market policy and remained the exclusive domain of the member states and the relevant national authorities. This was reflected in the fragmented state of the EU telecommunications services market.

Concerns grew about the ability of such a segmented market to adjust to, and efficiently exploit, the burst of major innovations in switching, transmission and equipment technologies in the 70s. Indeed the costs of developing and implementing these technologies are so substantial that no Member state national market is large enough for its public $\mathrm{TO}$ to be able to recoup these costs. In addition the effiency of some new services is likely to be impaired if they happen to be developed separately along different standards making intra-EU interoperability and interconnection difficult, costly and leading to long delays.

It is in response to these concerns that the Commission began to have an active policy concerning telecommunications in the middle of the 80s. In the remaining of this subsection, the sequence of policies adopted by the EU authorities are depicted. First, the policies of the period from 1984 to 1987 are presented as those of the first phase. Then the measures decided as a result of the adoption of the 1987 Green Paper on Telecommunications are summarized as those of the second phase. This is supplemented by the examination of the pre-competitive R\&D policy measures taken since 1987.

\section{C.1. The First Phase}

In 1984 started a first phase during which preparatory works and preliminary initiatives took place.

The program that was at the basis of the first phase comprised of five lines of action. One

49 See, for example, the 1992 Review of the Telecommunications Services Sector by the European Commission and the 1994 Bangemann Report. 
line of action was aimed at the initial co-ordination of future development of networks. It included efforts toward developing the ISDN, toward stimulating the ongoing transformation of the existing phone network into a fully digital network, toward setting the premises for introducing broadband communication, and toward developing digital mobile communication and a pan-European mobile communication network. A second line of action concerned the setting up of European-wide open standards for terminal equipments as a way to progress towards a Community-wide terminal equipment market. A third point of that first phase was the promotion of collaborative pre-competitive and pre-normative $R \& D$ and the definition of an important program for cooperative $R \& D$ in the field of telecommunications (RACE). A fourth set of actions dealt with the introduction of advanced services and improved networks in less favored peripheral regions. The consensus that telecommunications may serve as a tool to ease the economic and social development of these regions constituted the starting point of the STAR program. The last aspect of that phase consisted of efforts toward reaching a common EU position in international discussions with the objective to defend the EU interests in telecommunications.

This first phase shows thus a series of preliminary steps mainly geared toward harnessing new technologies by means of industrial policy measures. The construction of a unique market for telecom services however was not the explicit target of these various initial measures. The actions taken during the first phase and the results of the various studies they commended created a general consensus about the importance of telecommunications for EU economic growth and prosperity. This in turn led to the second phase which began in 1987.

\section{C.2. The Second Phase}

The target of that second phase was a reform of the sector and the elaboration of a global concept for its development so as to establish a properly functioning internal market which could sustain the efficient and timely development of new services and networks.

The first step of that second phase was the enlargment of the EU telecommunications policy with the adoption by the Council of the Green Paper on Telecommunications in 1988. This adoption implied the expansion of the policy in two ways: first, regulatory conditions were included, and second competition was to be progressively introduced in the sector. A second consequence of this adoption was the full integration of the EU telecommunications policy into the 1992 program for internal market completion.

Six objectives for the achievement of a Community-wide open telecommunications market were identified in this Green Paper and subsequently implemented via the adoption of a series of Directives shaping the regulatory environment in the field of the telecommunications. ${ }^{50}$ The measures taken in these decisions reflects an approach combining liberalization and harmonization.

The first objective was the liberalization of the supply and provision of terminal and network equipments. The main directives achieving this objective are the Commission

50 Many Directives, Decisions, Regulations, Recommendations, and Resolutions related to telecommunications have been adopted since 1984. Only some of the major directives will be mentioned in the text. 
Directive of 16th May 1988 on competition in the markets in telecommunications terminal equipment (88/301/EEC, OJ L 131/73, 27.05.88), the Council Directive of 29th April 1991 on the approximation of the laws of the Member States concerning telecommunications terminal equipment, including the mutual recognition of their conformity (91/263/EEC, OJ L 128/1,23.05.91), and the Council Resolution on the development of the common market for satellite communications services and equipment $(92 / \mathrm{C} 8 / 01$, OJ C 8/1, 14.01.92).

The second objective was the liberalization of services, with the temporary exception of public voice telephony (including fax) and the operation of the basic network. This objective was achieved mostly via the Commission Directive of 28th June 1990 on competition in the markets for telecommunications services $(90 / 388 / \mathrm{EEC}$, OJ L 192/10, 24.7.90). ${ }^{51}$

The third objective was the separation of the regulatory and operational functions in order to create efficient market structures.

The fourth objective was to ensure open access conditions to networks and interworking and interconnection (Open Network Provision). This objective was materialized essentially by the Council Directive of 28th June 1990 on the establishment of the internal market for telecommunications services through the implementation of open network provision (90/387/EEC, OJ L 192/1, 24.7.90), the Council Directive of 5th June 1992 on the application of open network provision for leased lines (OJ L 165, 19.06.92). These two Directives define the principles according to which services providers and users can have access to telecommunications networks and public services. Their objective is to guarantee an access that is harmonized, objective, transparent and non-discriminatory across the EU and among call-users and services providers.

The fifth objective was the stimulation of European standardization. The Commission supported three lines of actions: i) promotion and determination of standards that are believed to be "pro-competitive"; ii) encouragement of the use of European standards in public procurement; iii) prevention of adoption of standard by Member States that the Commission believes will inhibit the flow of trade. ${ }^{52}$ The creation of the European Telecommunication Standards Institute (ETSI) was the major action in this field. This Institute was founded in 1988 as a place favoring interactions for the elaboration of technical specifications. It is in permanent contact with other European and international organizations in charge of norms and standards in the field of telecommunications, such as CEN/CENELEC or CCITT. ${ }^{53}$

The sixth and last objective was the full application of competition rules to the sector. The Council Directive of 17th Septemeber 1990 on procurement procedures of entities operating the water, energy, transport, and telecommunications sectors (90/531/EEC, OJ

51 Telex, mobile telephony, radiopaging and satellite services were excluded from the scope of this Directive and thus were not liberalized. Intelligent fax, videotex, and data networks got liberalized early 1993.

52 See, Besen (1990).

53 A major achievement of the cooperative standardization efforts is the design of a pan-European norm for digital cellular telephony, GSM. The GSM norm is the main standard for digital cellular telephony in the EU and is developing with success in the rest of the world. See supra. 
L 297/1, 29.10.90) is one of the decisions that take care of this issue. The Guidelines on the application of EEC competition rules in the telecommunications sector (91/c233/02, OJ C 233/2, 06.09.91) published by the Commission provided its viewpoint concerning the global approach to this issue of how to apply EEC competition rules to this sector.

The implementation of these various directives is supervised by the Commission. As concerns competition in the telecommunications services sector a summary of the evolution of the relevant EU legislation is provided on a yearly basis in the annual competition reports. In these reports the degree of implementation of these liberalization and harmonization directives is also described. ${ }^{54}$ Actions taken against Member States that are not complying with the implementation deadlines are mentioned. Later the date of compliance to the directives is signalled. ${ }^{55}$

The EU authorities' concern to increase competition in the telecommunications services sector also shows in their attentive handling of mergers and joint ventures among telecom firms. Joint ventures aimed at developing a pan-European digital cellular mobile telephony system, such as the consortium ECR 900 among AEG Aktiengesellschaft (from Germany), Alcatel NV (of Franco-Dutch origin), and OY Nokia (from Finland) were given negative attestation on the basis of Art. 85 para. 3. Another example of granting exemption on the basis of Art. 85 para. 3 occured in the field of radiopaging. ${ }^{56}$ Ambitious alliances among major TOs (such as between British Telecom and MCI, or among Deutsche Telekom, France Telecoma and Spring) are under investigation.

Simultaneously, decisions were taken and efforts were made to continue and expand the set of actions started as part of the third and fourth lines of actions of the first phase: the promotion of collaborative pre-competitive and pre-normative R\&D and the definition of an important program for cooperative $R \& D$ in the field of telecommunications (RACE) and the introduction of advanced services and improved networks in less favored peripheral regions.

\section{C.3. The Continuity of the Pre-Competitive R\&D Policy}

The major Community R\&D program in the telecommunications sector, RACE, is a tenyear program adopted by the Council on 14th December 1987, the goal of which is the

54 See, for example, the 19th Report on Competition Policy (point 226), the 20th Report on Competition Policy (points 54-60, and 355), the 21st Report on Competition Policy (points 20-25, 8-82, 323-324, appendix II) and the 22nd Report on Competition Policy (points 30-37, and 511).

55 For example, regarding the implementation of the directive liberalizing the terminal equipment market, the 19th report identified Belgium, Denmark, Germany and Ireland as countries that still imposed restrictions on the supply of the first telephone set. The 20th report indicated that Denmark, Germany and Ireland lifted these restrictions and that infraction procedures were still in force against Belgium and Spain. The 21st report mentions that these two countries have abandoned their exclusive rights in supplying the first telephone set. See the 19th Report on Competition Policy (point 226), the 20th Report on Competition Policy (point 355), and the 21st Report on Competition Policy (point 323).

56 See the case of the joint venture between Irish Telecom and Motorola targetting the creation, promotion and exploitation of a radiopaging system for Ireland. See the 20th Report on Competition Policy (points 59 and 60). 
global development of integrated broadband communication. ${ }^{57}$ The strength of the project would lie in getting all the parties concerned about the evolution of telecommunications services (public TOs, equipment manufacturers, suppliers of new services, etc.) to cooperate extensively.

The first five-year phase (1988-1992) was part of the second R\&DT Framework Program and its budget amounted to $405 \mathrm{Mecu}$. The objective of this first phase was to promote the competitiveness of the telecommunications equipments and services industry so that consumers could benefit, without any delay and at low cost, from all telecom services necessary to sustain economic growth, employment and competitiveness.

During years 1988-1992, the focus of the RACE project was twofold. On the one hand, cooperative efforts were made to speed up the harmonization of the European infrastructure and to elaborate common functional specifications for the integrated broadband (high-capacity) communication networks and technologies carrying voice, data, and image signals. One satisfactory outcome was the transmission of several hundred of specification projects to various European and international normalization authorities. On the other hand, collaborative $R \& D$ work was done to implement the asynchronous transfert mode (ATM) for high-speed switching in digital communications, to improve techniques to manage networks, and to develop technologies and norms for HDTV and digital video. In addition collaborations between RACE and other pan-European R\&D programs such as Eureka or COST took place so as to optimize R\&D in the field of telecommunications.

Additional R\&D cooperative programs studying the use of advanced telecommunications services in other sectors started at the same time: AIM in the field of medicine, DELTA in the field of education, DRIVE in the field of transport. Also specific R\&D programs were launched then for electronic data interchange, for developing information services (IMPACT program), for assisting EU less-favored regions in telecommunications development (STAR program, followed by Programme Télématique ${ }^{58}$ ). Steps were made towards a common approach to the introduction of High Definition TeleVision (HDTV); this pan-European collaboration stopped later because the technique chosen for this cooperation turned out to be suboptimal. ${ }^{59}$

The results of RACE's first phase were assessed as positive and the lines of action for the

57 See the Council Decision of 14th December 1987 on a Community program in the field of telecommunications technologies, research and development (R\&D) in advanced communications technologies in Europe (RACE program) (88/28/EEC, OJ L 16/35, 21.01.88).

58 The STAR program benefited from a Community aid of nearly 770 millions ECUs for the period 19871991. This program heavily promoted investments in infrastructure ( 80 per cent of the budget was allocated to it) and stimulated the access to advanced telecommunications services by firms of the less favored regions (using the remaining 20 per cent of its budget). The Programme Télématique with a budget of 200 millions ECUs for 1991-1993 continued the actions started under STAR aimed at introducing advanced telecommunications systems into firms.

59 The EU cooperative efforts focused on an analogous mode of transmission. Their outcomes would most likely have been dominated by the results of other works based on a digital mode of transmission (and taking place in the USA). The major European firms that were involved in the analogous approach to HDTV have also been, and still are, participating in the R\&D aimed at a digital HDTV. 
second phase (1993-1997) were adopted in June 1991 so as to ensure continuity. ${ }^{60}$ While the first phase was more oriented toward evaluating the various options for integrated broadband communications (IBCs), the second phase is geared toward preparing the effective introduction of IBCs and further developing applications, services, and techniques for network operation and management. The Community cooperative R\&D activities in the field of telecommunications services (mainly RACE and Programme Télématique) was integrated into a global effort toward trans-European telecommunications networks by means of the adoption of the third Framework Program. ${ }^{61}$

\section{C.4. Towards a Third Phase}

As required by the 1990 Directives concerning competition in telecoms services and ONP framework (90/387/EEC, and 90/388/EEC) the results of the EU telecoms policy as well as the situation in the field of telecommunications were assessed in $1992 .{ }^{62}$ The report summarizing these evaluations was agreed to become the basis for a major round of consultations among the various parties involved in the telecommunications services sector. The issue of the debate was the type of policy to be adopted for the future given the growing importance of telecommunications: either to stop the liberalization process, or to implement an extensive regulation for tariffs and investments, or to fully liberalize all vocal telephony communications, or to partially liberalize them.

The round of consultations took place late 1992 and early 1993. ${ }^{63}$ This first led to a nuanced assessment of the situation in the telecommunications services sector. It was concluded that the special and exclusive rights held by TOs in each Member State (except the UK) caused EU telecoms services to be underdeveloped. ${ }^{64}$ Then participants unanimously voted in favor of a total liberalization of public vocal telephony. Finally a list of recommendations for the future development of the telecommunications services sector was issued, including a request for a precise calendar of the evolution of the regulation (with well-defined steps).

In response to the consultations, the Commission established a two-phase calendar in April 1993, which was adopted by the Council in July 1993. The first phase (1993-1995) would aim at reinforcing the implementation of existing legislations and at preparing

60 See the Final Report Concerning Phase 1 (1988-1992) of the Ten-year Program RACE, COM(93) 118 final, Brussels, 30.03.93.

61 See the Council Decision of 7th June 1991 adopting a specific research and technological development program in the field of communication technologies (1990-1994) (91/352/EEC, OJ L 192/8, 16.07.91). See the Council Decision of 7th June 1991 adopting a specific research and technological development program in the field of telematic systems in areas of general interest (1990-1994) (91/352/EEC, OJ L 192/8, 16.07.91).

62 See Commission of the European Communities, "1992 Review of the Situation in the Telecommunications Services Sector", SEC(92) 1048 final, Brussels, 21.10.92.

63 See the Commission's communication to the Council and the Parlement about these consultations, COM(93) 159 final, Brussels, 28.04.1993.

64 The identified bottlenecks are a lack of advanced services, the low availabilty of high-capacity leased lines, high cross-border tariffs, and insufficient cost-orientation of the tariffs. 
future pieces of regulation. The main objects for these legislations to come are the complete liberalization of public vocal telephony by 01.01 .1998 (with some derogations for Spain, Portugal, Greece and Ireland up to 2003, and for Luxemburg up to 2000) and necessary amendements to the EU regulatory framework for the telecoms (especially as concerns tariff structures, network interconnections and access conditions, and universal services). The second phase (1996-1998) would target the implementation of these new regulations.

Since the beginning of the first phase, reports on the concept, and the supply, of universal service in the telecommunication sector, a Green Paper on mobile communications and the first part of a Green Paper on the liberalization of telecommunications infrastructures and cable TV networks have been published. ${ }^{65}$ (Legislations on the basis of these documents are expected in 1995.)

The Council Resolution adopted at the end of 1993 reflected the position of the EU authorities as regards the universal service and the various problems to be tackled in order to prepare its liberalization. In that Resolution, universal service is defined as a minimum service of specified quality available to all users at an affordable price. The reduction of the divergence between tariffs and costs is viewed as necessary for two reasons. First, to alleviate the bottlenecks created by the non-cost orientation of the tariffs. And second to reduce distortions to effective competition between incumbent TOs and new entrants. ${ }^{66}$ The delicate issue of financing local and suscriber charges if crosssubsidies between international and local calls are to be substantially reduced will need to be carefully investigated. ${ }^{67}$ The solution to this problem should satisfy two criteria. First low-income households and rural areas should not be excessively affected by this tariff rebalancing. Second, inefficient new service suppliers not burdened by the universal services obligations should have no incentive to enter. To devise such a solution will require the evaluation of the costs of meeting these obligations. This task is likely to be difficult because these universal services obligations differ among Member States in terms of definition and implementation.

The Green Paper on mobile communication first provides a thorough assessment of the mobile communication situation in the EU as well as abroad from a technical and a regulatory point of view. Successful achievements, such as the creation of the efficient GSM digital norm, are pointed out and are contrasted with existing problems, such as the limited possibility of roaming, the lack of interoperability, or the difference in licence procurement procedures. Then it defines the fundamental principles and lines of actions for the future EU strategy and regulatory framework in mobile communications.

The Green Paper on telecommunications infrastructures consists of two parts. The first part focused on assessing the situation, on identifying the policy principles to be followed

65 See respectively COM(93) 543 final, Brussels, 15.11.93, COM(94) 145 final, Brussels, 27.04.1994, and COM (94) 440 final, Brussels, 25.10.1994.

66 One example of such a competition distortion is the incumbent TO's use of its revenues earned in monopoly markets to subsidize its operations in competitive market segments. A case of such internal crosssubsidies by Deutsche Telekom was investigated by the Federal Cartel Administration in Germany. It turned out that Deutsche Telekom channeled about DM 1.9 billion from its monopoly business to its data service division which is subject to market competition. (See Financial Times FIND REF

67 The magnitude of these cross-subsidies is estimated at about ECU 16 billion per year. 
and on establishing a plan of action (with a specific calendar). Present regulations concerning the use of existing infrastructures -those of public TOs and those of alternative carriers, such as railways, cable TV- are shown to create many constraints and so prevent from using efficiently and extensively existing infrastructure. An intervention aimed at lifting these constraints is presented as necessary to allow liberalization measures to be implemented in due time. In particular it is recommended that cable TV and railways operators could use their infrastructure to provide VANS and cross-border corporate voice communications within closed user groups (CUGs, which typically gather a firm headquarter and its subsidiaries and/or its suppliers). ${ }^{68}$ The adoption of such recommendation would create an regulatory-backed incentive to invest in new or upgraded infrastructure and so would help increasing the number of high-speed digital leased lines across the EU. The augmentation and improvement of infrastructure is viewed as desirable to allow the development of value-added services and to prepare for full liberalization of vocal telephony. The second part -to come- should prepare the debate concerning the issue of infrastructure regulations after that public vocal telephony is completely liberalized in 1998.

In addition, during the same period, the White Paper on "Growth, Competitiveness, Employment - The Challenges and Ways Forward into the 21st Century" acknowledged the importance of the development of an information society and of trans-European networks. ${ }^{69} \quad$ Information and communication technologies are identified as its foundations, having the potential to promote a steady and sustainable growth, increase competitiveness, open new job opportunities and improve the quality of life. ${ }^{70}$

The reflexion on this issue was continued by a group of experts led by the Commissioner Bangemann; its outcome was the submission of the report "Europe and the global information society - Recommendations to the European Council" to the European Council in June 1994. This reports supplements the White Paper analysis and provides concrete recommendations for action. In particular, the need to accelerate the liberalization process and the achievement and preservation of universal service is emphasized. Also the roles of the public authorities and of the private sector are defined. The former should set new rules for safeguarding competition in the telecommunications sector and should control their implementations. The later should develop the information infrastructure and finance it. In addition arguments are given to dare such substantial and quick investments: multiplicity of their impacts in various aspects of society (ten applications are described) and necessity of not falling behind the USA and/or Japan in the race towards a successful information society.

\section{C.5. Beginnings in Telecoms Services Trade Policy}

European trade policy in the telecommunications services sector could not really start before 1988 since the telecoms policy assignement were purely national until then.

68 This infrastructure opening up would not be extended to the entire voice market until 1998.

69 See Chapter 3 and Chapter 5 Section A in the White Paper on "Growth, Competitiveness, Employment The challenges and ways forward into the 21st century", Brussels, 1994.

70 See C.1.1. and C.1.2. supra. See also the 1994 White Paper on Growth, Competitiveness, and Employement and the 1994 Bangemann Report. 
However expectations of a trade policy role for the EU in the close future concerning telecommunications services were already justified in 1986 when the Uruguay Round was inaugurated in Punta del Sol. Indeed the themes of services (including telecommunications services) and intellectual property rights were on its agenda for the first time. ${ }^{71}$

Trade in telecommunications services like trade in other services differs from trade in goods. Indeed services can be exported in the traditional sense of the term only marginally; they require most of the time the presence of their supplier on the territory where they will be sold. Consequently usual trade barriers for goods (such as tariffs, quantity restraints, etc.) are often not relevant. Instead barriers to trade in services result frequently from administrative retrictions or organizational dispositions, such as abusive norms, licence procedures, cartels, access restrictions to the distribution systems, etc. This type of restrictions is more difficult to detect and control than the quantitative or tariffs restriction type seen in goods trade. Therefore the measures to be taken toward liberalizing the trade in services are likely to be more difficult to design and implement than reductions in tariffs.

In December 1993, the European Commission signed the Final Act of the Uruguay Round. The later incorporates the General Agreement on Trade in Services (GATS), the equivalent of GATT for all services of all sectors (except those supplied as part of the exercise of government power). ${ }^{72}$ Among other things, this signature represents a measure of trade policy for the telecoms because the telecommunications services are covered by the GATS. $^{73}$

The EU trade position implied by the GATT Final Act signature reflects the its desire for a progressive liberalization of the trade in telecoms. However the calendar along which progress toward free trade will take place in the telecommunications services is unknown. $^{74}$ In addition, negotiations will start on a bilateral basis with the hope that they will prepare the ground for multilateral negotiations.

The Commission is already involved in negotiations on basic telecoms services in the context of GATS and is actively participating in discussions addressing related issues such

71 During the discussions the intellectual property rights issue became excluded from the scope of the negociations. It does not appear in the Final Act. ADD REF

72 From GATT, GATS borrows the various requirements and disciplinary rules (Art. II to Art. XV), such as most favored nation clause, transparency requirement, specific commitments vis-a-vis developing countries, etc. Two important modalities according to which GATT Members should comply to their specific commitments are expressed in Art. XVI and Art. XVII: the former concerns market access and the later refers to nondiscriminatory treatment of non nationals. Art. XIX sets the progressiveness of the services trade liberalization. See Houard (1994), pp. 97-101.

73 The cable distribution and the diffusion of radiophonic and televisual programs are exempted from the application of GATS measures. This conflicts with the definition of the GATS's scope ("all services of all sectors except those connected to the exercise of governmental power"). It is too early to say how this conflict will be solved. See Houard (1994), p.101.

74 The schedule of the series of successive negotiations aimed at designing the measures that will lead to a progressive increase of liberalization is not determined. Only a deadline exists: at most five years after the entry into force of the World Trade Organization Agreement. See Houard (1994), p. 97 and 100. 
as intellectual property rights protection and mutual recognition agreements. ${ }^{75}$

This review of the main policy measures taken by the EU in the telecommunications services sector seems to highlight two facts: the first one concerns the evolution of the EU telecoms policy since its beginning, the second one relates to the comparison between the political decisions and theirs implementation.

The sequence of policy measures taken by the EU as regards telecoms services reveals a shift in its focus. During the early years (1984-1988) industrial policy dominated the sector and its measures were mainly directed towards technology achievements. The emphasis was on collaborative pre-competitive $R \& D$ in the techniques viewed essential for future development and on the elaboration of pan-European standards and technical specifications to ensure interoperability and interconnections. Since 1988 competition policy has been given priority and its measures have aimed at developing a properly functioning internal market for telecoms services. The two lines of actions adopted to achieve this goal have been liberalization and harmonization.

The comparison between the policy decisions and their implementation shows some discrepancy. On the one hand there exists a global consensus among all interested parties that in order to fully benefit from the fast technological evolution telecommunications services should be quickly liberalized and that adequate regulations should be adopted. On the other hand effective implementation of the EU directives dealing with the liberalization and harmonization of telecommunications services are continuously observed to be slow.

In the next section, the relationships among the trade, industry, and competition policies is examined in terms of coherence and conflicts.

\section{SECTION D: Analysis of the Coherence and Conflicts among these Policies}

The interactions among trade, competition, and industry, policies in the telecommunications sector are observed from both the viewpoints of goals and instruments. The analysis of the policies coherence and divergence is made along the following outline. First, a key aspect of the existing coherence among the three policies is expressed: competition in the telecoms services market is identified as a crucial. Second, the relationship between competition policy and industrial policy is examined, highlighting the role of standardization. Third the interactions between competition and trade policies are analysed, revealing much coherence in terms of objectives and pointing out to potential conflicts. Finally, the role of standards as a potential tool to improve the coherence among the three policies is explained.

\section{D.1. The Competition Priority}

The study of the European policy measures affecting the telecommunication services sector clearly indicates that competition as a goal has become the priority of the European

\footnotetext{
75 For additional detail, see European Commission, COM (94) 347 final.
} 
authorities. The 1987 Green Paper on Telecommunications, the 1992 Review of the Situation in the Telecommunications Services Sector, and the 1994 Bangemann Report all identify an increase in competition in the supply of telecommunications services as desirable. Such a competition increase is viewed as an essential means to optimally adjust to the rapid technological evolution and to guarantee firms the access to efficient communication services and equipment so as not to loose on the communication-related productivity ground and be ready for the information society challenge.

Market competition as a goal is stimulated and increased by two types of competition policy instruments: liberalization measures and harmonization measures. The former set of measures is aimed at progressively dismanteling the exclusive rights regulations existing in most Member States. Such regulations led to the emergence of one national public TO in each country and this monopolistic structure has been more and more perceived as suboptimal. The objective of the liberalization is the opening up of the sector to new operators and service suppliers. The goal of the second set of measures is double: first the creation of interoperability and interconnections among old networks, among new networks, and among new and old networks, and second the harmonization of regulations (such as procedures to obtain network or services licences, etc.). The purpose of these measures is to stimulate and make possible the completion of an efficient internal telecom market and the effective increase of competition. Indeed Communitywide services could not be solely guaranteed by the enforcement of competition rules and the freedom to provide services because of the existence of twelve technically diverging national networks. This explains the need to supplement liberalization measures with harmonization measures to ensure interoperability.

The competition priority and the target of full liberalization in the telecoms is unanimously agreed by all parties having interests in telecoms. ${ }^{76}$ This general consensus is also reflected in the White Paper "Growth, Competitiveness, and Employment" and in the Bangemann Report. Thus there seems to be no conflict on that point; there is even an agreement on the need to accelerate the liberalization.

However a lack of coherence appears between the expression of that will to liberalize the sector and the rate at which steps towards liberalization are actually implemented. Indeed the debate started about 10 years ago and today several key achievements -already pointed out as important in the 1987 Green Paper on the Development of the Common Market for Telecommunications Services and Equipments- have not yet been fully realized. Evidences of slow, or even absence of, implementation abound: for example, mailing by the Commission of formal warning letters to several Member States for failing to implement the competition in the telecommunication terminal equipment market Directive and the ONP leased line Directives; slow compliance to these warning letters; separation between regulatory and operational functions improperly implemented; weak reduction of the tariff border effect; new suppliers being denied the right to provide new formally liberalized services; etc. This suggests the existence of a strong political resistance in the Member States to implement the various liberalization and harmonization directives.

This slow implementation appears to be mainly caused by structural factors: some related to the supply-side of the market and others connected to political principles followed in

76 See the report on the general consultations organized by the European Commission, COM(93) 159 final, Brussels, 28.04.93. 
assigning tasks and functions between the EU and the Member States. On the supplyside of the telecoms services market, management and organizational features developed during the monopoly period (such as cross-subsidization, etc.) and the obligation to fulfil requirements that are not directly related to telecoms (such as financial contribution to the national budget, employment policy, etc.) are factors which have made, and make, the necessary modifications towards liberalization hard to enforce.

In terms of political distribution of competences, the principle of subsidiarity seems to have played a role in the discrepancy between the Directives and their implementations. ${ }^{77}$ The investigation of this fact is the object of a recent CEPS Working Document by J.-M. Sun and J.Pelkmans. ${ }^{78}$ According to these authors, the presence of significant cross-border externalities has weakened the possibility that subsidiarity leads to a rapid and efficient Directives implementation. Three important cross-border externalities are described as characterizing the telecommunications services sector. First, each additional subscriber to the network increases the value of the network for the existing users. Second, the functioning of one country's telecoms network influences the operations of other countries' networks as these networks are interconnected for the provision of international services. Third, the tariff setting procedure for international services (as organized through the ITU) creates a significant externality for the users reflected in the tariff frontier effect (cross-border tariffs being more expensive than similar calls within national borders). The charge that users calling abroad must pay includes a rate fixed by the foreign country where the call ends, and users have no control on this foreign tax. The existence of these cross-border externalities suggests that the collection of twelfe shemes of implementation, each optimal at its own local level (i.e., within the Member State) will not correspond to the optimal implementation at the European level. The first reason is that local actions are not able to internalize these cross-border externalities. The second reason is that a voluntary and credible policy coordination among Member States which could overcome this fragmentation is unlikely to emerge given the complexity of the coordination problem and given the beggar-thy-neighbor behaviors that these externalities permit. ${ }^{79}$

A similar problem of timing arises as concerns the harmonization of the sector. In that matter too, the speed of achievements does not correspond to the theoretical consensus: the former is slow while the latter is supportive of an accelerated harmonization. The reasons for this discrepancy are partly to be found in the numerous divergences existing

77 Subsidiarity is defined by Sun and Pelkmans as "an assignement principle which, given a set of policy objectives, is used to determine the optimal level of government at which various public economic functions should be undertaken." According to these authors, subsidiarity "assigns policy-making and implementation powers to local government, except when this would likely be ineffective, inefficient, inimical to others, or demonstrably unnecessary." See Sun and Pelkmans (1994), p.2.

78 This paragraph summarizes the main ideas of Sun and Pelkmans' contribution and refers the interested reader to the initial document: Sun, J.-M., and J. Pelkmans, "Why Liberalization Needs Centralization: Subsidiarity and EU Telecoms", CEPS Working Document No. 88, July 1994.

79 The authors propose a similar, but more detailed and nuanced, discussion to argue that the presence of these cross-border externalities constitute a strong rationale for actions at the EU level. They also show that the need for a centralized action is reinforced by the impossibility of a voluntary and credible coordination among Member States. In addition they illustrate how the present telecoms situation reflects the various implementation problems that subsidiarity can not easily overcome in the telecoms services sector. Finally they reach the conclusion that European telecoms should be assigned to the EU level of government if the sector is to be successfully liberalized. See Sun and Pelkmans (1994). 
among the installed networks as well as in the diversity of standards and regulatory procedures among the Member States. These factors make the necessary changes towards harmonization costly in two ways: the design and construction of interoperability and interconnection interfaces, and the search for a compromise about which standards and regulatory procedures to follow. The bearing of telecommunication standards upon economic competition is not only complex but also ambivalent. Both pro- and anticompetitive effects -sometimes concurrently and in a same market- can be generated by a given standardization activity. ${ }^{80}$

The difference between the dates of policy decisions (i.e., vote of Directives) and the dates of their effective implementation at the Member States level is likely to have undesirable consequences on the level of competition in the telecoms services sector. Indeed the slow pace of effective liberalization gives time to incumbent public TOs to strategically use the present revenues from exclusively provided telecoms services in ways apt to distort competition. One such strategic behavior able to impede competition is the use of the incumbent's present revenues from non-liberalized services to subsidize its operation in the competitive segment of the telecoms market. ${ }^{81}$ Evidence of such behavior was found in Germany by the Federal Cartel Administration: Deutsche Telekom had subsidized up to DM 1.9 billion its data services division (under competition) using its monopoly revenues. ${ }^{82}$ Another strategic use of these revenues from protected services is to invest in new services and infrastructures. The explicit justification is the need to modernize the networks and improve services availability. But a complementary, implicit reason is the desire to build, before the public vocal service liberalization is fully completed, barriers to entry against expected new entrants. These investments should give an important first mover advantage to the incumbents and help them to maintain their dominant position for a while after the liberalization deadline. It is to be noticed that this type of strategic behaviors add to a substantial, already existing barrier to entry to public vocal telephony: the well-established base of incumbent TOs for protected services and networks.

Another feature of the telecoms policy implementation is its localization and that of ensuing investments. In that aspect too some incoherence has been observed between the EU political will to promote and support the development of less favored regions by means of telecommunications and the implementation of the telecoms Directives at the Member State level. Of particular interest is the localization of the investment in new ISDN and broadband networks. On the one hand these high-capacity networks are presented as a key element to help less favored regions to develop and overcome the gap created by the distance with the country major activity centers. On the other hand investments in ISDN and broadband networks are made in major urban areas. Consequently these areas attract even more than before new activities because the existence of sophisticated telecoms services and infrastructures is viewed as important and matters in the decision to locate new business.

80 For a statement about pro- and anti-competitive effects of interface standardization, see David (1992)

81 For new entrants to sue incumbent TOs for unfair practices such as cross-subsidies between protected and competitive services operations is a costly and slow process because of legal requirements and procedures (often impeded by the lack of clarity in TOs' accountancy and the lack of dedication of the regulatory body when it remains too close to the TO).

82 See the Financial Time Survey, Telecommunications in Business, 15 June 1994, p.IV. 


\section{D.2. The Necessity of Standards: Industrial Policy "Behind the Scene"}

Given the initial regulatory situation and the technical evolution in the sector, competition policy has been identified as the most adequate policy to fulfil the objectives chosen by the European authorities for the telecommunications services. Consequently industrial policy in the telecom sector has been subjected to a secondary role: its measures should never impede the pursuit of greater competition. This is reflected, for example, in the restriction of cooperative $R \& D$ agreements to pre-competitive stages whenever possible. The scope of industrial policy has been the promotion of cooperative R\&D in telecommunication technologies and its related applications and the elaboration of panEuropean norms. ${ }^{83}$ The emphasis has been on standardization as a means to contribute to the harmonization efforts required by the competition policy.

The selection of a standard is a delicate task. When there is a large amount of uncertainty about the technical and economic merits of many variants, a first phase should typically involve experimentations. ${ }^{84}$ After this period of experimentations one, or perhaps, a small number of variants emerge as "standard practice" or "dominant design". After this first phase the selection then can be passive, i.e., through the competitive market mechanism. Or it can be active, such as when a dominant economic or policital actor decides that a particular variant should become the standard. Reality shows that the selection of the best design among the few remaining ones is frequently fortuitous (rather than the product of a systematic exploration of the merits of all possible variants): either the result of historical circumstances or the outcome of the strategic capabilities of certain agents.

When the development of a standard conforms to such a pattern, problems of selection and of timing are rather difficult. Industrial policy then should aim at building organizational systems involving a coordinated set of decentralized experimental projects, mechanisms and procedures for exchanging and distributing information produced in the course of these projects, and a centralized procedure of assessment to decide the standard to be selected and the timing to switch to the standardization phase. However such an organizational design is rather difficult to establish. ${ }^{85}$

The European experience of norms selection for the telecoms is based on setting up such an organizational system. Its outcomes confirms the above description. On the one hand the success of GSM pleads in favor of a centralized procedure. On the other hand the

83 See, for example, RACE and Programme Télématique for cooperative R\&D, and GSM and aborted HDTV for standards.

84 The first phase, also called extensive learning or "learning from diversity" phase involves experimentation with a variety of standard options. The objective is to gain a broad knowledge about as many potential avenues of development as possible, and then on its basis, make a sensible choice regarding which avenues are likely to be effective and are worth keeping for further investigation. Through the (negative) results of the experimentation this phase leads to the elimination of certain avenues of development.

85 One of the main problems to overcome is the incentive for agents to free-ride on participating to experimental projects (knowing that the final information will be widely shared in any case). 
failure of HDTV suggests the greater efficiency of the market. ${ }^{86}$ This refers to the issue of which policy, interventionist (i.e., industrial) or free market (i.e., competition), should prevail in the establishment of standards. In the case of the telecommunications services, the EU authorities seemed to have given priority to competition when a centralized standard turned out to be suboptimal compared with what the market developed and when the later did not threaten pan-European interoperability.

\section{D.3. Interactions among Trade and Competition Policies}

The question of conflict or coherence between trade policy and competition policy concerning the telecommunications services sector should be quick to settle. The reason is that the EU trade policy concerning these services is so recent that little material need to be examined. In principle, coherence seems to prevail up to now among the measures adopted by these two policies. Both policies follow a liberalization approach as shows in the GATS and various EU Directives. On the one hand EU competition policy steps towards liberalization offer opportunities for new telecoms services suppliers to enter the market as well as for TOs operating in one Member State to enter other Member States' telecoms market. On the other hand EU trade policy moves towards liberalization seek to expand the scope of the telecoms market opening up to other non-EU trade partners on a reciprocal basis. This is, non-EU TOs can enter the EU telecoms services market only if EU TOs can equivalently enter the telecoms services markets of these non-EU TOs.

However the outcome of this double commitment to liberalization in terms of increase in effective competition is uncertain for two reasons. First negotiations to implement the GATS in the telecommunications services sector are to take place on a bilateral basis to begin. And such an initial approach is likely to generate a mosaique of bilateral agreements reflecting the power of their parties more than an attempt to ease and optimize world trade in telecoms services. In addition the crucial issue of intellectual property rights has not yet been integrated in any formal multilateral agreement. This might seriously interfere with reaching satisfactory conclusions during the bilateral (and later multilateral) agreements concerning telecoms services requested by the GATS.

Second the expectations of a globalization of the telecoms services market and trade have led to a spurge of international strategic alliances among major public TOs within the EU and between the EU and the US. The main justification generally given by the members of these alliances is the need to combine assets (especially, networks) and skills in order to be able to provide on a world scale the quality and diversity of services to face the global competition to come. Although there is definite scope for efficient synergies and task reallocations, the concentration of market power induced by these strategic alliances constitutes a severe threat to future competition. Indeed the successful conclusion (including legal approval from relevant antitrust authorities) of these mega-alliances agreements before the sector complete liberalization may put the emergence of a competitive EU telecoms market at risk by destroying all incentives for potential new comers to enter this market. If this occurs the supply side of the EU market is likely to be

86 The HDTV case reveals the possibility that the central authority picks an inferior technology: the European cooperative efforts worked on an analoguous mode standard whereas private initiatives in the USA started -somewhat later but- on digital mode standards. The European authorities abandoned their project when its inefficiency became obvious. 
effectively reduced to a few alliances; this would generate an adequate context for collusive behaviors at the EU level.

American and European antitrust authorities are busy with assessing the desirability of each one of these alliances. Their task is extremely difficult. On the one hand the sector of telecommunications services knows a continuous flow of substantial technological innovations (many of them are not yet commercialized and new ones keep coming). This flow of innovations alters the structure of the supply at the same time as these strategic alliances influence this stream of inventions. The combined impact of this two-way interaction on potential competition is almost impossible to forecast. Therefore to assess in advance the pro- and anti-competitive effects of these alliances is extremely complex. On the other hand pressures may arise from the government and/or industry lobbies to allow some alliances even though they are evaluated as anti-competitive from a domestic point of view. To justify their demand these authorities and pressure groups are likely to refer to the need to give the national industry a means to enter foreign markets perceived as closed and to participate to global competition. In the absence of a world antitrust authority the risk of an escalade of strategic alliances exists. This is, governments authorize alliances -although assessed as apt to distort competition- as a response to similar authorizations in rival trade blocks (with the first country to move being motivated by the desire to extract foreign surplus). Such a scenario would parallel wellknown results of the strategic trade literature: active strategic industrial policy by all countries can lead to suboptimal equilibrium when there exists no institution forcing countries not to adopt actions that are individually appealing but collectively inefficient.

Another aspect of the interactions among competition and trade policies concerns the relationship between harmonization and trade liberalization, the other pillar of competititon policy. According to David (1992), to achieve harmonization within free trade areas like the EU is likely to be a long and exhausting process. The reasons are the complexity of telecommunications standards and their potential interactions with national economic interests. Indeed standards that encourage the growth of international trade in telecommunications equipments and services are likely to create immediate winners and losers. In addition because few countries have progressed very far in their efforts to privatize telecommunications, harmonization may generate direct conflicts of interests between policymakers in charge of negotiating harmonization agreements and policymakers responsible for state telecommunications enterprises. These facts suggest that a probable outcome of such harmonization agreements is the erection in effect of non-tariff barrriers. They also hint at the deep difficulties to be expected in coming years during the implementation process of the harmonization agreements in the telecoms services sector.

\section{D.4. Standards as a Potential Tool to Increase Coherence Among these Policies}

Given the respective definitions of the three types of policies (competition policy referring to the EU as a single market, trade policy revealing the EU as an agent in the world competition, and high-tech sector industrial policy considering the EU as a system of innovations) standards seem to be able to play a critical role in ensuring a greater coherence among these policies as concerns the telecommunications services sector. First competition policy needs standardization to achieve harmonization in the telecommunications services sector. Second trade policy needs standardization as a focusing device allowing national technical resources and organizational capacities of the 
telecommunications services sector to be efficiently integrated in the world competition. Third, industrial policy needs standardization to generate positive network economies through an increase in interoperability and compatibility among the various telecommunications networks and equipments.

Standardization however is only potentially a tool for ensuring coherence because of the possibility of some policy bias in the procedures of standardization. For instance, the HDTV is an example of trade policy bias in the standardization procedure whereas numerous cases of standards introduced too early (and consequently ending prematurely the experimentation phase) are examples of a competition policy bias. Nonetheless the establishment of decentralized procedures and of mechanisms of coordination for the elaboration of anticipatory standards still appears as one of the most efficient ways to improve the coherence of the three policies in the telecommunications services sector.

\section{CONCLUSIONS}

The investigation of the telecommunications services sector, as a one of the high tech sectors, allows to identify typical problems that EU policy-makers have to handled when a sector evolves rapidly from a technological point of view and when the objective is to create an efficient internal market. First, R\&D activities have to be efficiently organized when it comes to the development of systems and networks. Indeed the proper functioning of these techniques at a pan-European level requires interoperability and interconnection (which have to be taken into account as early as at the R\&D level). In the same way the selection of norms which is connected to this R\&D policy matters, but there is no recipe to always conclude it with success. Second, the technology dynamics exerts a strong pressure on the regulatory environment. The coordination of the regulatory decisions resulting from this pressure is necessary in order to avoid the erection of non tariff barriers. Third the globalization of trade requests a careful evaluation of how to face increase competition from abroad. In a sector where networks matters, private responses to the globalization challenge include the creation of strategic alliances. The emergence of such global alliances is a difficult question to be dealt with by antitrust authorities because the impact of these alliances on potential competition is hard to predict given the various forces altering the structure of the market.

In the particular case of the telecommunications services sector, EU policy-makers have reached a consensus about the objective which should be given priority: competition. However closer examination indicates that this consensus has not been enough to achieve the desired liberalization and harmonization. First of all, lags between the Directives and their implementation are often important. Causes are found among structural factors. Second, the need to maintain a reasonable degree of effective competition at the EU level seem to conflict with the some of the strategies adopted by EU firms to remain competitive in the world market. The way antitrust authorities are going to solve this dilemma is not known yet; it is likely that their decision will have an important impact on how the sector is going to evolve. Third, standardization seems to have a role to play in improving the coherence among the trade, industry, and competition policy in the telecommunications services sector; however its implementation is difficult. 


\section{REFERENCES}

- Bangemann, M. et al., "Europe and the Global Information Society: Recommendations to the European Council", June 1994, reprint in Cordis focus, Supplement 2, 15.07.94.

- Besen, S., "The European Telecommunications Standards Institute", Telecommunications Policy, December 1990, pp.521-530.

- CAWSON, A., K. MORGAN, D. WEBBER, P. HOLMES, and A. STEVENS, "Hostile Brothers: Competition and Closure in the European Electronics Industry", Oxford: Clarendon Press, 1990.

- CAWSON, A., G. SHEPHERD, and D. WEBBER, "Governments, Markets, and Regulation in the West European Consumer Electronics Industry", in Capitalism, Culture and Economic Regulation, L. HANCHER and M. MORAN (eds), Oxford: Clarendon Press, 1990.

- COMMISSION DES COMMUNAUTES EUROPEENNES, "Les programmes communautaires de recherche", 2e edition, Bonn: Economica Verlag, Mai 1990.

- Commission des Communautés Européennes, Livre vert sur une approche commune dans le domaine des communications par satellites dans la Communauté européenne: Vers des systèmes et des services à l'échelle de l'Europe, Communication de la Commission, $\operatorname{COM}(90), 490$ final, Bruxelles, 25.06.92.

- Commission des Communautés Européennes, "Tarifs des télécommunications dans la Communauté: Vers l'orientation des tarifs sur les coûts et l'ajustement des structures de prix", Communication de la Commission, SEC(92) 1050 final, Bruxelles, 25.06.92.

- Commission des Communautés Européennes, "L'industrie européenne des équipements de télécommunications: situation, enjeux, propositions d'action", Communication de la Commission, Bruxelles, 25.06.92.

- Commission of the European Community, "1992 Review of the Situation in the Telecommunications Services Sector", Communication by the Commission, SEC(92) 1048 final, Brussels, 21.10.92.

- Commission des Communautés Européennes, "Programme de R\&D sur les technologies de pointe dans le domaine des télécommunications en Europe (RACE): Rapport final concernant la Phase 1 (1988-1992) du programme décenal RACE", COM(93) 118 final, Bruxelles, 30.03.93.

- Commission des Communautés Européennes, "Programme IMPACT: Les événements et les développements les plus importants qui ont eu lieu sur le marché des services d'information électroniques 1991", Rapport de la Commission au Conseil, au Parlement Européen et au Comité Economique et Social, COM(93) 156 final, Bruxelles, 19.04.93.

- Commission des Communautés Européennes, "Communication au Conseil et au Parlement Européen sur la consultation sur l'examen de la situation dans le secteur des services de télécommunications", COM(93) 159 final, Bruxelles, 28.04.93. 
- Commission des Communautés Européennes, "Développement d'un service universel dans un environnement concurrentiel, Proposition de Résolution du Conseil sur des principes en matière de service universel dans le secteur des télécommunications", Communication de la Commission au Conseil, au Parlement Européen et au Comité Economique et Social, COM(93) 543 final, Bruxelles, 15.11.93.

- Commission des Communautés Européennes, Croissance, compétitivité, emploi: les défis et les pistes pour entrer dans le XXIe siècle: livre blanc, Luxembourg, 1994.

- Commission of the European Communities, Panorama of the EU Industry 94, Luxembourg, 1994.

- Commission of the European Communities, "Europe's Ways to the Information Society. An Action Plan", Communication from the Commission to the Council and the European Parliament, and to the Economic and Social Committee and the Committee of Regions, $\operatorname{COM}(94) 347$ final, Brussels, 19.07.94.

- Commission des Communautés Européennes, Vers un environnement de communications personnelles: Livre vert sur une approche commune dans le domaine des communications mobiles et personnelles au sein de l'Union Européenne, Communication de la Commission, COM(94) 145 final, Bruxelles, 27.04.94.

- Commission des Communautés Européennes, Livre vert sur la libéralisation des infrastructures de télécommunications et des réseaux de télévision par cable (1e partie: Principe et calendrier), Communication de la Commission, COM(94) 440 final, Bruxelles, 25.10.94.

- DASGUPTA, P. and P.A. DAVID, "The new economics of science", CEPR Discussion Paper nr. 320, Stanford University, 1992.

- DAVID, P.A., "Reputation and agency in the historical emergence of the institutions of 'open science'", CEPR Discussion Paper, nr. 261, Stanford University, 1991.

- DAVID, P., "The Economics of Compatibility Standards and Competition - A Report to the German Monopolies Commission", Koln, January 1992.

- DAVID, P.A., "Knowledge, property and the system dynamics of technological change", World Bank Annual Conference on Development Economics, Washington D.C., 1992

- DAVID, P.A. and FORAY, D., "Accessing and expanding the science and technology knowledge-base: a framework for interpreting available quantitative measures, OECDDSTI-CSPT, 1994

- David, P., and D. Foray, Institustions, Incentives and the Nature of Externalities in the Process of Knowledge Generation, Conference in honor of G.B.Richardson, Oxford University, St. John's College, January 1995.

- DAVID, P.A. and WRIGHT, G., "Resource abundance and American economic leadership", CEPR Discussion Paper, nr. 267, Stanford University, 1991.

- DAVID, P.A., MOWERY, D. and E. STEINMUELLER, "Analysing the economic pay off 
from basic research", Economics of innovation and new technology.

- European Parliament, "Emerging Technologies -Information Networks and the European Union-", Directorate General for Research Working Papers, Economic Series W11, Luxembourg, 1993.

- EYMANN, A., and L. SCHUKNECHT, "Antidumping Enforcement in the European Community", in Antidumping: How It Works and Who Gets Hurt, J. FINGER (ed), Ann Harbor: The University of Michigan Press, 1993, pp.221-239.

- Financial Times Survey, "Telecommunications in Business", June 15, 1994.

- Financial Times Survey, "Computer Networking", June 28, 1994.

- Financial Times Survey, "Mobile Telecommunications", September 17, 1994.

- Financial Times Survey, "New Broadcast and Communication Media", October 4, 1994.

- Financial Times Survey, "International Telecommunications", October 17, 1994.

- FORESTER, T., "Silicon Samurai: How Japan Conquered the World's IT Industry", Cambridge, Mass.: Blackwell Publishers, 1993.

- GATT, "Trade Policy Review: European Communities 1993", vol. 1, Geneva: General Agreement on Tariffs and Trade, 1993.

- GATT, "Trade Policy Review: European Communities 1993", vol. 2, Geneva: General Agreement on Tariffs and Trade, 1993.

- HAREL, T., and L. SOETE, "Industrial and Competition Policy in the EC", report prepared for the United Nations Industrial Development Organization, Merit: Maastricht, February 1993.

- Grupp, H., and T. Schnoring, "Research and Development in Telecommunications", in Telecommunications Policy, January/February 1992, p.46-

- Houard, J., "Le GATT et l’Uruguay Round", in Tendances Economiques, n.6, mai 1994.

- JAFFE, HENDERSON and TRAJTENBERG, "Geographic localization of knowledge spillovers", Quaterly Journal of Economics, 1993.

- MACHLUP, F., "The economics of information and human capital", Princeton University Press, 1984.

- MURPHY, A., "The European Community and the International Trading System", vol.2, CEPS Paper n.48, Bruxelles: Centre for European Policy Studies, 1990.

- NICOLAIDES, P., "The Trade Policy of the European Community: Legal Basis, Instruments, Commercial Relations", Maastricht: the European Institute of Public Administration, 1993. 
- OECD, "Assessing the Effects of the Uruguay Round", Paris: OECD, 1993.

- OECD, "Trade and technology: issue paper", DSTI/STP, 1993.

- ORDOVER, J., and W. BAUMOL, "Antitrust Policy and High-Technology Industries", Oxford Review of Economic Policy, vol.4, n.4, 1988, pp.13-34.

- PELKMANS, J., "The Significance of EC-1992", The Annals of the American Academy of Political and Social Sciences, n.531, January 1994, pp.94-111.

- ROMER, P., "Implementing a national technology strategy with self-organizing industry investment boards", Brooking Papers, 1993.

- SAPIR, A., P.BUIGUES, and A. JACQUEMIN, "European Competition Policy in Manufacturing and Services: a Two-Speed Approach?", Oxford Review of Economic Policy, Vol. 9, n.2, 1993, pp.113-132.

- SOETE, L., "National Support Policies for Strategic Industries: The International Implications", Merit Working Paper n.91-006.

- SOETE, L., and A. ARUNDEL, "An Integrated Approach to European Innovation and Technology Diffusion Policy: a Maastricht Memorandum", Luxemburg: publication n.

- STIGLITZ, J., "Social absorbtion capability and innovation, CEPR Discussion Paper 292, Stanford University, 1991.

- Sun, J.-M., and J. Pelkmans, "Why Liberalisation Needs Centralisation? Subsidiarity and EU Telecoms", CEPS Working Document No. 88, July 1994.

- EUR 15090 EN of the Commission of the European Communities, May 1993.

- WEDER and GRUBEL, "The new growth theory and Coesan economics: institutions to capture externalities", Weltwirtschaftliches Archiv. 


\section{APPENDIX}

Notice that this first appendix is supplemented by three additional one: Appendix A, Appendix B, and Appendix C.

Table 1: EU Telecommunications Services: Receipts, Surplus, and Employment in 1993

\begin{tabular}{|l|l|l|l||}
\hline country & $\begin{array}{l}\text { 1993 receipts } \\
\text { (US\$ million) }\end{array}$ & $\begin{array}{l}\text { 1993 surplus } \\
\text { (US\$ million) }\end{array}$ & $\begin{array}{l}1993 \text { employment } \\
\text { (thousand) }\end{array}$ \\
\hline B & 3207 & 270 & 25.6 \\
\hline DK & 2613 & 241 & 17.0 \\
\hline D & 35679 & -1738 & 231.0 \\
\hline GR & 1556 & 303 & 26.3 \\
\hline E & 10193 & 747 & 74.3 \\
\hline F * & 25372 & 899 & 167.8 \\
\hline IRL & 871 M Irl Pound & 81 M Irl Pound & 13.0 \\
\hline I & 14872 & 418 & 87.9 \\
\hline L & n.a. & n.a. & n.a. \\
\hline NL & 5944 & n.a. & n.a. \\
\hline P & 204.7 MMPTE & 9.9 MMPTE & 10.0 \\
\hline UK ** & 20576 & 2659 & 156 \\
\hline \hline
\end{tabular}

Source: IDATE, Réseaux, No. 8, Special 200, Novembre 1194, p.20-21.

Notes: ${ }^{*}$ : Data linking France Télécom to Cogecom.

** : Data concerning British Telecom only; figures for Mercury not available.

Table 2: Telecommunications Services: Distribution of Main Lines

\begin{tabular}{||l|l|l|l|l|l||}
\hline country & $\begin{array}{l}\text { lines per } 100 \\
\text { hab. } 1980\end{array}$ & $\begin{array}{l}\text { lines per } 100 \\
\text { hab. 1991 }\end{array}$ & country & $\begin{array}{l}\text { lines per } 100 \\
\text { hab. 1980 }\end{array}$ & $\begin{array}{l}\text { lines per 100 } \\
\text { hab. 1991 }\end{array}$ \\
\hline B & 24 & 41 & DK & 42 & 58 \\
\hline D* & 26 & 49 & GR & 23 & 39 \\
\hline E & 18 & 31 & F & 25 & 49 \\
\hline IRL & 13 & 27 & I & 21 & 38 \\
\hline L & 35 & 48 & NL & 33 & 47 \\
\hline P & 10 & 21 & UK & 29 & 46 \\
\hline USA & $/$ & 51.5 & Japan & $/$ & 45.2 \\
\hline
\end{tabular}

Source: European Commission, SEC(92) 1050 final, p32

The 1994 Panorama of the EU Industry, p.25-16.

note: $\mathrm{D}^{*}$ means figures referring to former West Germany. 
Table 3: Electronic Information Services in the EU

\begin{tabular}{|c|c|c|}
\hline & 1991 & growth (\%) 90/91 \\
\hline Employment & 28805 & 8.5 \\
\hline Turnover (ECU million) & 3283 & 12.2 \\
\hline $\begin{array}{l}\text { Geographic distribution of online revenues in \%: } \\
\text { - National consumption } \\
\text { - Intra-EC trade } \\
\text { - Total EC domestic } \\
\text { - Exports }\end{array}$ & $\begin{array}{l}34.7 \\
36.0 \\
70.7 \\
29.3\end{array}$ & $\begin{array}{l}39.4 \\
35.3 \\
37.3 \\
18.2\end{array}$ \\
\hline $\begin{array}{l}\text { Turnover by subject content, in \%: } \\
\text { - Finance } \\
\text { - Business } \\
\text { - Science, technology, medecine } \\
\text { - Government } \\
\text { - Other }\end{array}$ & $\begin{array}{l}63.9 \\
27.4 \\
3.2 \\
3.3 \\
2.2\end{array}$ & $\begin{array}{l}3.7 \\
24.5 \\
94.0 \\
143.0 \\
295.7\end{array}$ \\
\hline $\begin{array}{l}\text { Turnover by services, in \% } \\
\text { - Online information services } \\
\text { - Offline information services }\end{array}$ & $\begin{array}{l}90.9 \\
9.1\end{array}$ & $\begin{array}{l}14.3 \\
4.9\end{array}$ \\
\hline
\end{tabular}

Source: The 1994 Panorama of the EU Industry, p.25-10

Table 4: Information Services Market by Delivery of Support in the EU

\begin{tabular}{|l|l|l|l||}
\hline Million ECU & 1990 & 1995 & Average \% growth/yr 1990/95 \\
\hline ASCII Terminal & 1580 & 3100 & 14 \\
\hline Videotex & 300 & 600 & 15 \\
\hline Audiotex & 220 & 580 & 21 \\
\hline CD-Rom & 20 & 220 & 6 \\
\hline Total & 2120 & 4500 & 16 \\
\hline
\end{tabular}

Source: The 1994 Panorama of the EU Industry, p.25-2.

Table 5: EU Analogous and Digital Cellular Radiotelephony

\begin{tabular}{||l|l|l|l|l|l||}
\hline Country & Anal. Norm & $\begin{array}{l}\text { Anal. } \\
\text { Suscribers } \\
\text { (thousand) }\end{array}$ & $\begin{array}{l}\text { Av. growth } \\
\text { rate /yr }\end{array}$ & $\begin{array}{l}\text { Digital } \\
\text { Subscribers } \\
\text { (thousand) }\end{array}$ & $\begin{array}{l}\text { GSM } \\
\text { Introduction } \\
\text { Date }\end{array}$ \\
\hline B & NMT450 & 66 & $14 \%$ & $/$ & $/$ \\
\hline DK & NMT450 & 47 & $-6 \%$ & $\begin{array}{l}\text { TO:6 } \\
\text { DMT:15 }\end{array}$ & $03 / 92$ \\
\hline DMT900 & 185 & $23 \%$ & $\begin{array}{l}\text { D1:190 } \\
\text { D2:260 }\end{array}$ & $07 / 92$ \\
\hline E & C-Netz & 807 & $9 \%$ & $/$ & $/$ \\
\hline
\end{tabular}




\begin{tabular}{|c|c|c|c|c|c|}
\hline $\begin{array}{l}\text { F: FT } \\
\text { SFR }\end{array}$ & $\begin{array}{l}\text { RC2000 } \\
\text { NMT450 }\end{array}$ & $\begin{array}{l}331 \\
125\end{array}$ & $\begin{array}{l}1 \% \\
23 \%\end{array}$ & $\begin{array}{l}\text { FT:15 } \\
\text { SFR:7 }\end{array}$ & $\begin{array}{l}07 / 92 \\
07 / 92\end{array}$ \\
\hline IRL & TACS900 & 50 & $25 \%$ & / & / \\
\hline I & $\begin{array}{l}\text { RMTS } \\
\text { TACS900 }\end{array}$ & $\begin{array}{l}35 \\
950\end{array}$ & $\begin{array}{l}-33 \% \\
39 \%\end{array}$ & 1 & $10 / 92$ \\
\hline $\mathrm{L}$ & NMT450 & 0.9 & $0 \%$ & 3.4 & $07 / 93$ \\
\hline NL & $\begin{array}{l}\text { NMT450 } \\
\text { NMT900 }\end{array}$ & $\begin{array}{l}27 \\
170\end{array}$ & $\begin{array}{l}4 \% \\
33 \%\end{array}$ & / & / \\
\hline $\mathrm{P}$ & C-Netz & 30 & $30 \%$ & / & / \\
\hline $\begin{array}{c}\text { UK:BT } \\
\text { M }\end{array}$ & $\begin{array}{l}\text { TACS900 } \\
\text { TACS900 }\end{array}$ & $\begin{array}{l}711 \\
895\end{array}$ & $\begin{array}{l}23 \% \\
19 \%\end{array}$ & 1 & $12 / 91$ \\
\hline
\end{tabular}

Source: 1994 Green Paper on Mobile Telecommunications, p.82

Table 6: Telecommunications Services: Gross Investments (million ECU)

\begin{tabular}{|l|l|l|l|l|l||}
\hline Country & 1980 & 1991 & Country & 1980 & 1991 \\
\hline B & 426.3 & 668.7 & DK & 250.4 & 355.7 \\
\hline D & 3956.9 & 11870.2 & GR & 177.8 & 440.9 \\
\hline E & 1175.4 & 4846.9 & F & 4028.5 & 4959.7 \\
\hline IRL & 190.6 & 222.1 & I & 2052.4 & 6499.9 \\
\hline L & 17.9 & 51.6 & NL & 510.8 & 1312.0 \\
\hline P & 106.5 & 426.6 & UK & 2030.5 & 3659.1 \\
\hline
\end{tabular}

Source: The 1994 Panorama of the EU Industry. p.25-14. 